\title{
HUBUNGAN PERAN STAKEHOLDERS DENGAN PARTISIPASI MASYARAKAT DALAM PROGRAM AGROPOLITAN DESA KARACAK KECAMATAN LEUWILIANG KABUPATEN BOGOR
}

\section{The Relationship between Role of the Stakeholders and Community participation in Agropolitan Program in Karacak Village, Leuwiliang Subdistrict, Bogor District}

\author{
Siska Oktavia*) dan Saharuddin \\ Departemen Sains Komunikasi dan Pengembangan Masyarakat, Fakultas Ekologi Manusia, IPB \\ *)Email : phoenik_91@yahoo.com
}

\begin{abstract}
Agropolitan is a program which seeks to reduce disparities between towns and villages. This program was implemented through human resource development, agriculture development, capital development and improvement of infrastructure facilities. There are three purposes of this study, that is to analyze the level and form of community participation in the agropolitan program, to analyze the role of stakeholders in the agropolitan program of Karacak village, Leuwiliang subdistrict, Bogor district and to analyze the relationship between the role of the stakeholders with the level of community participation. The research was carried out by quantitative and qualitative methods using questionnaires and in-depth interview guide. The results of this study indicate that the level of community participation is at the level of tokenisme in all phases of the program with the participation of the dominant forms of participation contribute opinions. The results of testing the hypothesis clarify that there is a relationship between the role of stakeholders and community participation in the implementation. That is, the higher level of stakeholders roles will be higher level of community participation.
\end{abstract}

Keywords: agropolitan, participation, stakeholders

\begin{abstract}
ABSTRAK
Agropolitan merupakan suatu program yang bertujuan untuk mengurangi perbedaan antara perkotaan dan pedesaan. Program ini diterapkan melalui pengembangan sumberdaya manusia, pengembangan pertanian, pengembangan modal dan peningkatan faislitas infrastruktur. Terdapat tiga tujuan pada peneltian ini yaitu, untuk menganalisis tingkat dan bentuk partisipasi masyarakat dalam program agropolitan, untuk menganalisis peran stakeholders dalam program agropolitan di Desa Karacak, Kecamatan Leuwiliang, Kabupaten Bogor, dan untuk menganalisis hubungan antara peraturan pengambil kebijakan dengan tingkat partisipasi masyarakat. Penelitian ini menggunakan pendekata metode kuantitatif dan kualitatif dengan alat bantu kuesioner dan wawancara mendalam. Hasil penelitian ini mengindikasikan bahwa tingkat partisipasi masyarakat secara keseluruhan program agropolitan berada pada tahap tokenisme yang memiliki kesempatan untuk berpendapat. Hasil dari pengujian klarifikasi hipotesis menunjukkan terdapat hubungan antara peran stakeholders dengan partisipasi masyarakat dalam penyelenggaraan program agropolitan. Sehingga, semakin tinggi tingkat peran stakeholders akan semakin tinggi pula tingkat partisipasi masyarakat.
\end{abstract}

Kata kunci : agropolitan, partisipasi, stakelolders

\section{PENDAHULUAN}

Fenomena pembangunan ekonomi yang sentralistik di perkotaan yang selama ini diterapkan telah menyebabkan disparitas ekonomi antara perkotaan dengan pedesaan. Kesenjangan pertumbuhan wilayah tersebut juga terjadi karena lemahnya keterkaitan antara desa dan kota yang memunculkan gagasan pengembangan kawasan pedesaan yang mampu menangani urban bias. Hal ini menyebabkan ketertinggalan perkembangan kehidupan sosial ekonomi di pedesaan, seperti: rendahnya kesejahteraan, tingkat pendidikan, terbatasnya ketersediaan lapangan pekerjaan, kurangnya akses transportasi, dan fasilitas umum lainnya di pedesaan. Data penduduk Indonesia tahun 2011 mengenai perbandingan tingkat kesejahteraan masyarakat, menunjukkan kenyataan bahwa kawasan pedesaan masih tertinggal jika dibandingkan dengan perkotaan. Terbukti dengan perbandingan jumlah penduduk miskin di perdesaan dengan perkotaan pada tahun 2011. Jumlah penduduk miskin di pedesaan hingga tahun 2011 mencapai 18.9 juta jiwa, jauh lebih tinggi dibandingkan penduduk miskin perkotaan, yaitu 11 juta jiwa.

Daerah suburban merupakan sebuah kawasan yang masyarakatnya telah terperangkap dalam suatu transformasi meninggalkan pertanian tetapi masih belum didominasi 
oleh kegiatan-kegiatan industrial, maka dari itu banyak masyarakat di daerah suburban yang mencari nafkah pada sektor informal yang tidak teratur. Ketidakteraturan ini terlihat bagaimana pekerja sektor informal khususnya pedagang makanan yang mengambil public area seperti pinggir jalan atau trotoar, dan menjual makanan yang tidak bersih.

Konsep pembangunan yang menawarkan solusi untuk permasalahan tersebut salah satunya diwujudkan dalam program agropolitan (Rustiadi 2007). Pentingnya agropolitan dalam pembangunan ekonomi daerah pedesaan adalah mengurangi disparitas antar daerah karena terjadinya "pendaerahan" pengelolaan pembangunan ekonomi akibat UU No 32 tahun 2004 yang mengatur otonomi daerah seperti dijelaskan oleh Amalia (2006). Program agropolitan tersebut direalisasikan menjadi program nasional yang tertera dalam Rencana Jangka Panjang Pembangunan Nasional (RJPN) tahun 2005-2025, pada point 32 yang menyebutkan bahwa agropolitan merupakan salah satu program yang akan diusung untuk pembangunan pedesaaan terutama pedesaan yang berbasiskan pada pertanian.

Kabupaten Bogor merupakan salah satu wilayah agropolitan berbasiskan pertanian dengan SK. Mentan No.312/TU.210/ $\mathrm{A} / \mathrm{X} / 2002$ yang menjelaskan tentang pengembangan kawasan agropolitan di Kabupaten Bogor. Sesuai dengan persyaratan pembagian zonasi kawasan agropolitan yang harus memperhatikan: komoditas unggulan, kondisi agroklimat, kondisi sumberdaya manusia, kelembagaan, kependudukan, aspek posisi geografis kawasan agropolitan dan ketersediaan infrastruktur, maka Desa Karacak terpilih menjadi salah satu desa pusat agropolitan di Kabupaten Bogor yang memiliki komoditi unggulan buah manggis.

Pelaksanaan program agropolitan sudah berlangsung sejak tahun 2005 di Indonesia, namun keberhasilan program yang ditandai dengan sustainability program agropolitan, belum tercapai. Di Kabupaten Bogor, hasil evaluasi pelaksanaan agropolitan Propinsi Jawa Barat oleh BAPPEDA Jawa Barat tahun 2010 menjelaskan bahwa terdapat beberapa kelemahan program agropolitan diantaranya: belum optimalnya peran masing-masing sektor baik di tingkat propinsi maupun kabupaten, masih lemahnya perlindungan terhadap petani terutama terkait kepemilikan lahan, benih/ bibit dan harga jual hasil produksi.

Berdasarkan rencana program pengembangan kawasan agropolitan di Kabupaten Bogor masa proyek 20052010, program agropolitan di desa Karacak sudah selesai tanpa ada keberlanjutan. Keberhasilan pelaksanaan program agropolitan sangat ditentukan oleh keterlibatan, termasuk masyarakat yang merupakan aktor utama dalam pembangunan yang harus diprioritaskan partisipasinya dimulai dari proses sosialisasi, perencanaan, pelaksanaan sampai evaluasi program untuk mewujudkan tujuan utama dari agropolitan serta keberlanjutan program di kawasan agropolitan. Selain itu pelaksanaan program juga melibatkan stakeholders yang menghasilkan peran stakeholders yang berasal dari pengaruh dan kepentingan stakeholders terhadap program agropolitan. Melalui kerjasama dengan masyarakat dalam pengembangan program agropolitan, harapannya seluruh pihak yang berkepentingan nantinya mampu memahami program secara utuh mulai dari proses perencanaan sampai evaluasi. Indikator keberhasilan program agropolitan yang berupa pengembangan infrastruktur kawasan agropolitan dan sistem usaha agribisnis yang baik dapat diukur dengan adanya peningkatan infrastruktur serta kemajuan agribisnis setelah adanya program agropolitan. Proses pengembangan kawasan agropolitan di Kecamatan Leuwiliang khususnya Desa Karacak memerlukan usaha bersama dalam pemahaman terhadap karakteristik wilayah, juga melibatkan peran aktif semua stakeholders dalam menggambarkan kemampuan kawasan agropolitan. Selama ini program agropolitan seringkali mengandalkan peran pemerintah, mulai dari penyusunan masterplan sampai pembentukan POKJA dan POSKO agropolitan di setiap kabupaten. Sedangkan masyarakat sebagai "obyek program" belum terlihat eksistensinya. Tanpa keterlibatan semua stakeholders, baik LSM, pihak swasta maupun pemerintah dengan peran yang proporsional serta kerjasama dengan masyarakat maka tidak terjadi keberlanjutan program.

\section{Pertanyaan Penelitian}

Berdasarkan kondisi tersebut perlu dipelajari lebih lanjut untuk melihat bagaimana bentuk dan tingkat partisipasi masyarakat dalam program agropolitan sesuai dengan tangga partisipasi arnestein (1969) yang dibagi menjadi non-partisipasi, tokenisme dan citizen power. Selain itu, perlu juga melihat peran stakeholders yang dilihat dari variabel pengaruh dan kepentingan pada setiap tahapan program mulai dari perencanaan, pelaksanaan dan evaluasi. Perlunya mengetahui keterkaitan antara peran stakeholders dengan partisipasi masyarakat menyebabkan perlu pengujian terhadap hubungan pengaruh peran stakeholders terhadap partisipasi masyarakat dalam setiap tahapan program pembangunan agropolitan. Peran stakeholders juga perlu di perlihatkan melalui posisi stakeholders dalam klasifikasi stakeholders.

\section{Tujuan Penelitian}

Guna menjawab rumusan masalah dan pertanyaan penelitian tersebut, maka tujuan penelitian antara lain: 1) Menganalisis peran stakeholders dan posisi masing-masing stakeholders berdasarkan dalam klasifikasi stakeholders selama penyelenggaraan program agropolitan di Desa Karacak Kecamatan Leuwiliang Kabupaten Bogor. 2) Menganalisis tingkat partisipasi dan bentuk partisipasi masyarakat dalam setiap tahapan program agropolitan di Desa Karacak Kecamatan Leuwiliang Kabupaten Bogor. 3) Menganalisis hubungan antara peran stakeholders dengan tingkat partisipasi masyarakat dalam tahapan program agropolitan di Desa Karacak Kecamatan Leuwiliang Kabupaten Bogor.

\section{Kegunaan Penelitian}

Hasil penelitian ini diharapkan dapat berguna bagi berbagai pihak, terutama pihak yang berkepentingan dengan program agropolitan, antara lain: 1) Bagi akademisi, penelitian ini diharapkan dapat menjadi bahan referensi dan kajian untuk penelitian selanjutnya tentang hubungan peran stakeholders dengan partisipasi masyarakat dalam program pembangunan khususnya agropolitan. 2) Bagi pemerintah, penelitian ini diharapkan dapat menjadi bahan pertimbangan dalam penetapan kebijakan program agropolitan kedepan sehingga lebih mengarahkan kepada partisipasi masyarakat pada tingkatan kemandirian dalam pelaksanaan program. 3) Bagi masyarakat, dapat memberikan pemahaman tentang peran yang dilakukan oleh stakeholders dalam program agropolitan sehingga 
dapat mempengaruhi partisipasi masyarakat. Penelitian ini juga diharapkan dapat menambah pengetahuan bagi masyarakat dalam mengoptimalkan partisipasi masyarakat, khususnya dalam program agropolitan.

\section{PENDEKATAN TEORITIS}

\section{Tinjauan Pustaka}

Secara lebih luas pengembangan kawasan agropolitan diharapkan dapat mendukung terjadinya sistem kota-kota yang terintegrasi. Djakapermana (2003), menyatakan bahwa pengembangan kawasan agropolitan menjadi sangat penting dalam konteks pengembangan wilayah mengingat kawasan dan sektor yang dikembangkan sesuai dengan keunikan lokal. Selain itu pengembangan kawasan agropolitan dapat meningkatkan pemerataan mengingat sektor yang dipilih merupakan basis aktifitas masyarakat. Keberlanjutan dari pengembangan kawasan dan sektor menjadi lebih pasti mengingat sektor yang dipilih mempunyai keunggulan kompetitif dan komparatif dibandingkan dengan sektor lainnya. Penetapan pusat agropolitan terkait dengan sistem pusat-pusat nasional, propinsi, dan kabupaten (RTRW Propinsi/Kabupaten) sehingga dapat menciptakan pengembangan wilayah yang serasi dan seimbang. Menurut Rivai dalam Tarsudi (2003), tujuan pengembangan kawasan agropolitan adalah untuk meningkatkan pendapatan dan kesejahteraan masyarakat melalui percepatan pengembangan wilayah dan peningkatan keterkaitan desa dan kota dengan mendorong berkembangnya sistem dan usaha agribisnis yang berdaya saing berbasis kerakyatan, berkelanjutan dan terdesentralisasi (wewenang berada di pemerintah daerah dan masyarakat) di kawasan agropolitan.

Menurut Freedman (1975), stakeholders merupakan kelompok dan individu yang dapat mempengaruhi dan/atau dipengaruhi oleh pencapaian tujuan dari sebuah program. Stakeholders juga diartikan sebagai mereka yang memiliki kepentingan dan keputusan tersendiri, baik sebagai individu maupun wakil kelompok. Individu, kelompok, maupun komunitas dan masyarakat dapat dikatakan sebagai stakeholders jika memiliki karakteristik seperti yang diungkapkan oleh Budimanta dkk (2008), yaitu mempunyai: kekuasaan, legitimasi, kepentingan terhadap program.

Analisis stakeholders diperlukan untuk mengetahui peran masing-masing stakeholders yang merupakan semua aktor atau kelompok yang mempengaruhi dan/atau dipengaruhi oleh kebijakan, keputusan dan tindakan dari sebuah program. Analisis stakeholders dilakukan menggunakan metode pendekatan yang dikembangkan oleh Groenendijk (2003) untuk mengetahui peranan dan fungsinya. Metode tersebut diawali dengan mengidentifikasi stakeholders yang terlibat dan mengklasifikasikan berdasarkan keterkaitannya secara langsung/tidak langsung dengan proyek yang ada. Kemudian, tiap stakeholders yang berbeda tersebut tentunya memiliki atribut yang berbeda untuk dikaji sesuai dengan situasi dan tujuan dari analisis. Atribut yang dimasukkan dalam analisis adalah pengaruh (power) dan kepentingan (importance).

Menurut Reed et al. (2009), analisis stakeholders dilakukan dengan cara: (1) melakukan identifikasi stakeholders; (2) mengelompokkan dan membedakan antar stakeholders; dan (3) menyelidiki hubungan antar stakeholders. Menurut
Bryson (2004) dan Reed et al. (2009) untuk memperjelas peran masing-masing stakeholders dapat menggunakan matriks pengaruh (influence) dan kekuatan (power) dengan membedakan stakeholders ke dalam beberapa kategori key players, context setters, subjects, dan crowd. Bisa juga menggunakan metode power and interest grid (IFC 2007) yang mengklasifikasikan stakeholders menjadi manage closely, keep statisfied, keep informed dan monitor dengan menggunakan matriks pengaruh (power) dan kepentingan (interest). Kepentingan (importance) merujuk pada kebutuhan stakeholders dalam pencapaian output dan tujuan (Reed et al. 2009) sedangkan kekuatan (power) merujuk pada pengaruh stakeholders pada metode power and interest grid merujuk pada kekuatan pengaruh yang dimiliki stakeholders untuk mengontrol proses dan hasil dari suatu keputusan. Penjelasan dari klasifikasi stakeholders adalah sebagai berikut:

1. Context setter atau keep statisfied memiliki pengaruh yang tinggi tetapi sedikit kepentingan. Oleh karena itu, mereka dapat menjadi risiko yang signifikan untuk harus dipantau.

2. Key player atau manage closely merupakan stakeholders yang aktif karena mereka mempunyai kepentingan dan pengaruh yang tinggi terhadap pengembangan suatu proyek/program.

3. Subjects atau keep informed memiliki kepentingan yang tinggi tetapi pengaruhnya rendah dan walaupun mereka mendukung kegiatan, kapasitasnya terhadap dampak mungkin tidak ada. Namun mereka dapat menjadi pengaruh jika membentuk aliansi dengan stakeholders lainnya.

4. Crowd atau monitor merupakan stakeholders yang memiliki sedikit kepentingan dan pengaruh terhadap hasil yang diinginkan dan hal ini menjadi pertimbangan untuk mengikutsertakannya dalam pengambilan keputusan. Pengaruh dan kepentingan akan mengalami perubahan dari waktu ke waktu, sehingga perlu menjadi bahan pertimbangan.

Ariyani (2007), seseorang untuk dapat berpartisipasi dalam pembangunan ada tiga prasyarat, yaitu adanya kesadaran pada diri yang bersangkutan tentang adanya kesempatan, dan adanya kemauan (sikap positif terhadap sasaran partisipasi) serta didukung oleh kemampuan (inisiatif untuk bertindak dengan komitmen). Kemauan dan kemampuan merupakan potensi yang dimiliki oleh pelaku secara individu maupun kelompok.

Tingkatan partisipasi merupakan derajat tingkat keterlibatan masyarakat dalam sebuah program terlihat dari kesempatan masyarakat untuk terlibat dan mempengaruhi jalannya program. Merujuk pada makalah yang berjudul "A Ladder of Citizen Participation" dalam Journal of The American Planning Association (1969), Arnstein mengemukakan delapan tangga atau tingkatan partisipasi yang menunjukan tingkat keterlibatan masyarakat dalam sebuah program, yaitu: Manipulation (Manipulasi), Therapy (Terapi), Informing (Menginformasikan), Consultation (Konsultasi), Placation (Menenangkan), Partnership (Kemitraan), Delegated Power (Kekuasaan didelegasikan), Citizen Control (Kontrol warga negara).

Tingkat partisipasi tersebut kemudian dibagi menjadi tiga level derajat partisipasi (Gambar 1). Tingkat manipulasi dan terapi termasuk kedalam level non-partisipasi, yang 
menjelaskan bahwa program pembangunan tidakbermaksud untuk memberdayakan masyarakat tetapi membuat pemegang kekuasaan untuk "mendidik" komunitas dengan memberikan pelajaran dan pelatihan namun masyarakat tetap tidak memiliki kesempatan memberikan pendapat. Tingkatan partisipasi informasi dan konsultasi termasuk dalam level tokenisme, dimana komunitas mendapatkan informasi dan mampu menyuarakan pendapat demi perbaikan program tetapi tidak ada jaminan kalau pendapat komunitas akan diakomodasi atau diimplementasikan dalam programnya. Keputusan terakhir tetap berada pada pemegang kekuasaan, masyarakat hanya diberi kewenangan searah untuk berpartisipasi dengan memberikan pendapatnya. Placation sebagai level tertinggi dalam tokenisme, mampu memberikan kesempatan kepada komunitas untuk memberikan pendapat kepada pemegang kekuasaan namun penentuan tetap berada pada pemegang kekuasaan. Tingkatan kemitraan juga memberikan kesempatan kepada komunitas untuk bernegosiasi dan terlibat dalam pengambilan keputusan. Tingkatan terakhir yaitu citizen power, pada tahapan ini masyarakat memiliki kewenangan yang besar terhadap penentuan program, dan pelaksanaan program. Tiga level terakhir termasuk kedalam level kekuatan warga negara (citizen power).

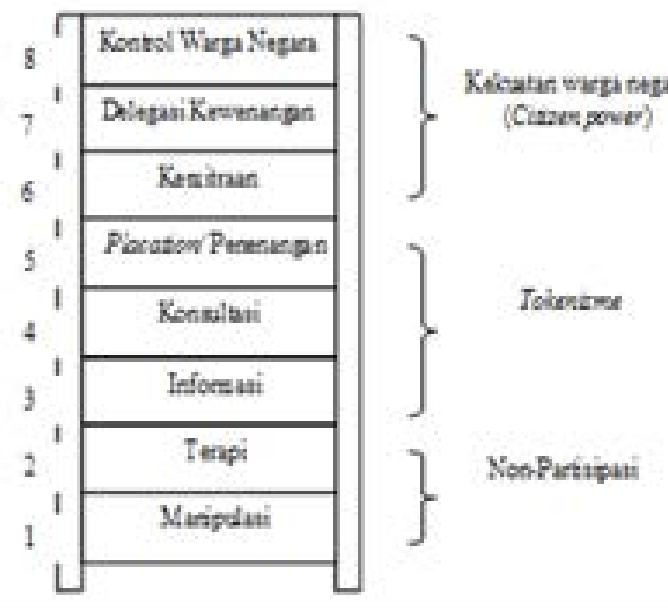

Gambar 1. Delapan Tingkatan dalam Tangga Partisipasi Masyarakat

\section{Kerangka Pemikiran}

Program pengembangan kawasan agropolitan ditujukan untuk memaksimalkan potensi daerah setempat, baik ditingkat nasional, provinsi, kabupaten maupun desa. Kesuksesan program ditentukan oleh keberhasilan dari indikator pengembangan Sumber Daya Manusia (SDM), pengembangan budidaya, pengembangan permodalan dan peningkatan fasilitas infrastruktur. Pelaksanaan program agropolitan terbagi dalam tahapan perencanaan tahun 20042005, pelaksanaan tahun 2005-2010 dan evaluasi tahun 2010. Penyelenggaraan program agropolitan melibatkan stakeholders seperti halnya program pembangunan lainnya.

Keterlibatan stakeholders menghasilkan peran stakeholders yang dapat dilihat dari pengaruh stakeholders dan kepentingannya bagi masyarakat (IFC 2007). Pengaruh stakeholders diukur dari dukungan dana terhadap program, jaringan yang dimiliki serta personality pihak masingmasing stakeholders. Variabel lain yang mempengaruhi peran stakeholders adalah tingkat kepentingan stakeholders menurut masyarakat terkait dengan pentingnya keberadaan pihak tersebut dilihat dari tujuan keterlibatan stakeholders untuk kepentingan masyarakat, kepentingan organisasi atau kepentingan individu stakeholders tersebut. Peran stakeholders selama program yang didapatkan dari analisis stakeholders menurut Groenendijk (2003) serta ditampilkan melalui kuadran dengan metode power and interest grid (IFC 2007) yang dilihat dari perencanaan, pelaksanaan dan evaluasi program agropolitan. Peran masyarakat juga dipengaruhi oleh posisi pihak yang berkepentingan tersebut dalam klasifikasi stakeholders menurut pengaruh dan kepentingannya.

Salah satu elemen penting dalam program agropolitan adalah keterlibatan komunitas yang merupakan pelaku utama dalam proses pengembangan kawasan, karenanya diperlukan partisipasi komunitas dalam setiap tahapan program. Oleh karena itu perlu dilihat tingkat partisipasi dan bentuk partisipasi masyarakat dalam tahap perencanaan, pelaksanaan yang terbagi menjadi pelaksanaan program pengembangan SDM, pengembangan budidaya, dan peningkatan fasilitas infrastruktur serta tingkat partisipasi masyarakat dalam evaluasi program. Pengukuran partisipasi masyarakat dilihat dari derajat wewenangnya dalam pengambilan keputusan dan digolongkan menjadi tingkatan non partisipasi, tokenisme dan citizen power oleh Arnestein (1969). Pada proses menjalankan program tentunya terdapat interaksi antara masyarakat dengan stakeholders sehingga memungkinkan melihat hubungan antara peran stakeholders dengan partisipasi masyarakat. Dalam prosesnya juga diteliti hubungan antara masingmasing elemen peran yaitu pengaruh dan kepentingan yang dihubungkan pula dengan partisipasi masyarakat pada setiap tahapan program agropolitan.

\section{Hipotesis Penelitian}

1. Diduga terdapat perbedaan peran dan posisi masing-masing stakeholders pada tahapan program agropolitan.

2. Diduga terdapat perbedaan tingkat partisipasi dan bentuk partisipasi masyarakat pada setiap tahapan program agropolitan.

3. Diduga terdapat hubungan antara peran stakeholders yang disebabkan oleh pengaruh dan kepentingan stakeholders dengan partisipasi masyarakat dalam program agropolitan.

\section{PENDEKATAN LAPANGAN}

\section{Metode Penelitian}

Penelitianinimenggunakan metodekuantitatifdan didukung oleh data kualitatif. Pendekatan kuantitatif dilakukan melalui wawancara dengan menggunakan kuesioner kepada responden yang merupakan anggota kelompok tani di Desa Karacak. Hasil informasi kuantitatif melalui kuesioner kemudian dikode, diolah melalui Microsoft Excel 2007 dan SPSS 17.0 lalu dianalisis. Pendekatan kualitatif dilakukan melalui wawancara mendalam kepada responden dan informan untuk mengetahui informasi lebih dalam mengenai peran stakeholders dan penyelenggaraan program agropolitan secara keseluruhan. 


\section{Lokasi dan Waktu Penelitian}

Penelitian tentang hubungan peran stakeholders dengan partisipasi masyarakat dalam program agropolitan ini dilaksanakan di Desa Karacak Kecamatan Leuwiliang, Kabupaten Bogor mulai agustus sampai oktober 2012. Pemilihan lokasi tersebut dilakukan secara sengaja (purposive) dengan alasan bahwa Desa Karacak merupakan salah satu desa yang pada tahun 2004 ditetapkan oleh pemerintah sebagai salah satu desa agropolitan di Kabupaten Bogor yang masuk ke dalam Zona I atau Zona utama program agropolitan sesuai dengan pembagian zona agropolitan. Hal ini menyebabkan wilayah tersebut menjadi sasaran utama program agropolitan sekaligus menjadi pusat aktivitas agropolitan.

\section{Teknik Pengumpulan Data}

Data primer diperoleh dari hasil kuesioner yang disebarkan dan dijawab oleh 30 responden yang merupakan anggota kelompok tani di Desa Karacak yang didapatkan melalui teknik pengambilan sampel acak (simple random sampling) yang dilihat berdasarkan jumlah anggota dari 3 kelompok tani yang terdapat di Desa Karacak Selain itu, wawancara mendalam juga dilakukan terhadap informan. Sedangkan data sekunder diperoleh melalui studi literatur yang sumbernya berasal dari berbagai dokumen pemerintah desa, dinas POKJA, masterplan agropolitan serta penelitian sebelumnya yang terkait dengan program agropolitan. Data kuantitatif ini digunakan untuk menggambarkan tingkatan dan partisipasi masyarakat serta peran stakeholders dalam program agropolitan. Data kualitatif didapatkan melalui wawancara mendalam kepada informan kunci yaitu pemerintah desa setempat, ketua POSKO agropolitan di Desa Karacak, dan pihak dinas ketua POKJA agropolitan yaitu BAPPEDA Kabupaten Bogor.

\section{Teknik Pengolahan dan Analisis Data}

Data kuantitatif yang dikumpulkan diolah dengan menggunakan program komputer SPSS 17 for Windows untuk menguji hubungan antar variabel yang kemudian dianalisis dan diinterpretasikan untuk melihat fakta yang terjadi dengan menggunakan analisis Uji Korelasi Rank Spearman untuk melihat hubungan antara variabel dengan data yang berbentuk ordinal, yaitu mengukur tingkat keterlibatan melalui peran stakeholders serta hubungannya dengan tingkat partisipasi. Peran stakeholders dilihat dengan penyusunan matriks pengaruh dan kepentingan dilakukan atas dasar pada deskripsi pertanyaan responden yang dinyatakan dalam ukuran kuantitatif (skor) dan selanjutnya dikelompokkan menurut kriteria. Analisis stakeholders dilakukan dengan penafsiran matriks kepentingan dan pengaruh stakeholders terhadap pengembangan program agropolitan dengan menggunakan stakeholders grid dalam metode power and interest grid (IFC 2007) dengan bantuan microssoft excel untuk menentukan angka pada setiap indikatornya, kemudian disandingkan sehingga membentuk koordinat.

\section{HASIL DAN PEMBAHASAN}

\section{Gambaran Umum Desa Karacak}

Desa Karacak merupakan salah satu dari sembilan desa yang ada di Kecamatan Leuwiliang. Desa Karacak merupakan desa agropolitan di kawasan zona satu dalam masterplan agropolitan yang berfungsi sebagai sentra pengumpul untuk komoditi manggis di Kabupaten Bogor. Desa Karacak dibagi menjadi 17 kampung dan lima dusun. Total luas wilayah Desa Karacak adalah 710.02 ha. Sebagian besar luas wilayah desa Karacak ditinjau dari aspek penggunaannya digunakan untuk perkebunan dan persawahan yang menggunakan hampir $89 \%$ luas desa sedangkan pengunaan untuk pemukiman masyarakat hanya $6.7 \%$ dari luas desa.

Jumlah masyarakat desa ini mencapai 10.862 jiwa yang terbagi ke dalam 2.855 kepala keluarga (KK) dengan proporsi yang seimbang antara jumlah masyarakat perempuan dan laki-laki, yaitu sebanyak 5.549 jiwa untuk masyarakat laki-laki dan 5.313 jiwa untuk masyarakat perempuan. Masyarakat Desa Karacak didominasi oleh penduduk usia muda hal ini dapat disebabkan karena banyak masyarakat yang menikah pada usia muda dan berakibat juga pada tingkat pertumbuhan penduduk yang relatif tinggi. sebagian besar masyarakat yang sekolah hanya mampu mencapai tahap Sekolah Dasar (SD) yaitu sebanyak 1.078 jiwa, kemudian jumlah warga yang tamat Sekolah Menegah Pertama (SMP) hanya 828 jiwa, dan jumlah yang tamat SMA hanya 864 jiwa. Jumlah tersebut tidak mencapai $10 \%$ dari total penduduk Desa Karacak. Sebagian besar penduduk adalah petani. Petani yang mengerjakan lahannya maupun buruh tani dengan persentase sebanyak $89 \%$, kemudian sebagian kecil masyarakat menggantungkan hidupnya dengan bekerja sebagai karyawan perusahaan, PNS, pedagang keliling, buruh bangunan, dan sebagainya. Proporsi terluas dari wilayah desa ini berupa lahan perkebunan yang menghasilkan hasil kebun dan dimanfaatkan masyarakat sebagai sumber mata pencaharian masyarakat. Oleh karena itu, sebagian besar masyarakat Desa Karacak memiliki mata pencaharian sebagai petani tanaman pangan. Hal tersebut sesuai dengan data kepemilikan lahan pertanian tanaman pangan.

Sebagian besar masyarakat pekerjaannya sebagai petani, namun masih ada 1.364 petani yang tidak memiliki lahan atau sekitar $47.8 \%$ petani tidak mengerjakan lahan milik sendiri. Kondisi ini diperparah dengan kepemilikan lahan yang kurang dari 1 ha sebanyak $51.3 \%$ dari total 2.885 rumah tangga petani atau bisa disimpulkan juga bahwa setengah dari jumlah petani di Desa Karacak merupakan petani gurem.

Sebagai kawasan agropolitan, Desa Karacak yang merupakan desa pertanian harus didukung dengan kelembagaan pertanian yang baik. Dukungan lembaga pertanian baik secara formal maupun non formal di Desa Karacak termasuk baik. Lembaga eksternal yang membantu antara lain adalah PKBT-IPB, Dinas Pertanian, UPTD Kecamatan Leuwilang, PPL (Penyuluh Pertanian Lapang) dari BP3K Kecamatan Leuwilang, BPP (Balai Penyuluh Pertanian), dan KTNA (Kontak Tani).

Lembaga tersebut memiliki peranan masing-masing yang membantu petani untuk menyelesaikan permasalahan pertanian yang terjadi di kawasan agropolitan terutama terkait komoditi unggulan Desa Karacak yaitu manggis. PKBT-IPB biasanya bekerjasama dengan ketua POSKO berperan bagi pembinaan teknis bagi para petani dengan mendatangkan ahli dibidang budidaya pertanian dan membina petani serta memberikan pinjaman dana kepada masyarakat Desa Karacak. 


\section{Gambaran Umum Program Agropolitan}

Program agropolitan dilaksanakan melalui penetapan POKJA agropolitan dengan penguatan Surat Keputusan Bupati No.590/191/Kpts/Huk/2004 yang berisikan informasi kerjasama antara pemerintah dengan pihak masyarakat untuk mempersiapkan kawasan agropolitan. Tahapan program agropolitan yang disesuaikan dengan indikasi program yaitu tahap perencanaan, pelaksanaan dan evaluasi. Langkah-

Program agropolitan dilaksanakan melalui penetapan POKJA agropolitan dengan penguatan Surat Keputusan Bupati No.590/191/Kpts/Huk/2004 yang berisikan informasi kerjasama antara pemerintah dengan pihak masyarakat untuk mempersiapkan kawasan agropolitan. Tahapan program agropolitan yang disesuaikan dengan indikasi program yaitu tahap perencanaan, pelaksanaan dan evaluasi. Langkah-langkah yang penting dalam penerapan agropolitan menurut pedoman pengelolaan ruang kawasan sentra produksi pangan nasional dan daerah agropolitan (2002) dan indikasi program agropolitan adalah:

1. Penyusunan masterplan pengembangan kawasan agropolitan yang akan menjadi acuan wilayah/ propinsi Kabupaten Bogor. Penyusunan ini dilakukan oleh pemerintah Kabupaten Bogor dengan perwakilan masyarakat dari wilayah Bogor bagian barat. Penyusunan ini berada diawal program yaitu tahun 2004. Masterplan ini disusun dengan bantuan akademisi yaitu Institut Pertanian Bogor yang diwakili oleh P4W-IPB bersama dengan POKJA agropolitan yang telah ditetapkan. Disusun dalam jangka panjang (10 tahun), jangka menengah (5 tahun) dan jangka pendek (1-3 tahun) yang bersifat rintisan. Sebagai awalan wilayah agropolitan Kabupaten Bogor hanya meliputi 11 wilayah yaitu Kecamatan Leuwiliang, Nanggung, Jasinga, Cigudeg, Sukajaya, Tenjo, Cibungbulang, Parung Panjang, Leuwisadeng, dan Pamijahan. Masterplan agropolitan juga menjelaskan matriks kegiatan lintas sektor, dan penanggung jawab kegiatan awal yaitu BAPPEDA Kabupaten Bogor.

2. Penetapan lokasi agropolitan, yaitu di wilayah Bogor bagian barat. Kegiatannya dimulai dari usulan penetapan kabupaten oleh Pemerintah Propinsi. Dilanjutkan dengan penetapan di tingkat kabupaten. Pemerintah Kabupaten Bogor kemudian menentukan kawasan agropolitan dengan melakukan identifikasi potensi dan masalah untuk mengetahui kondisi dan potensi lokasi (komoditas unggulan). Potensi lokasi yang harus diperhatikan antara lain: potensi SDA, SDM, kelembagaan, dan iklim usaha. Penetapan ini dibantu oleh pihak akademisi yaitu P4W-IPB dalam penyusunan masterplan. Penetapan komoditi unnggulan juga ditetapkan di tahap ini, syarat komoditi unggulan tersebut harus memiliki keunikan, bernilai ekonomis tinggi dan banyak terdapat dikawasan tersebut. Maka dipilihlah komoditas manggis sebagai ikon agropolitan Kabupaten Bogor, selain karena kualitasnya yang bagus sehingga layak diekspor, buah ini juga banyak terdapat di daerah Bogor Barat.

3. Sosialisasi program agropolitan dilakukan kepada seluruh stakeholders yang terkait dengan pengembangan program agropolitan baik di pusat maupun di daerah, sehingga pengembangan program agropolitan dapat lebih terpadu dan terintegrasi. Sosialisasi merupakan suatu upaya untuk memasyarakatkan gagasan, ide, atau konsep agar dapat diterima oleh masyarakat dengan pemahaman yang sama. Upaya sosialisasi pengembangan agropolitan dimaksudkan untuk menyamakan dan menyatukan persepsi, penilaian, pemahaman, serta gerak langkah dalam mengembangkan agropolitan. Sosialisasi agropolitan di Kabupaten Bogor dimulai tahun 2004 di tingkat kabupaten maupun tingkat desa. Sosialisasi ini penting sebagai langkah awal karena pengembangan agropolitan melibatkan banyak pihak dan kepentingan. Sasaran sosialisasi adalah jajaran pemerintah daerah, swasta, dan masyarakat khususnya yang berada di kawasan Bogor Barat. Sosialisasi diwujudkan dengan lokakarya awal di tingkat desa. Lokakarya awal digerakkan oleh BAPPEDA menghasilkan POKJA agropolitan, dilanjutkan sosialisasi di tingkat desa yang mengundang seluruh elemen masyarakat. Indikator upaya sosialisasi ini adalah interaksi antar stakeholders melalui suatu pemahaman dan penerapan yang sama untuk mengembangkan agropolitan.

4. Pengembangan kawasan agropolitan yang merupakan hasil dari sosialiasi program agropolitan tentunya harus mampu dipahami oleh masyarakat sehingga memerlukan fasilitator yang berada di tingkat desa maka di bentuklah POSKO (Pos Simpul Koordinasi) dan kemudian diadakan pelatihan fasilitator setiap bulannya.

Program agropolitan di Kabupaten Bogor terbagi menjadi beberapa program dan sub program yang tertera dalam masterplan agropolitan. Program pertama berupa program peningkatan produktivitas pertanian komoditi potensial yang terbagi menjadi sub program: 1) program peningkatan sumberdaya manusia masyarakat tani; 2) program pengembangan komoditas potensial; dan 3) program peningkatan kualitas sumberdaya lahan. Program kedua adalah pengembangan sistem tataniaga dan pemasaran yang dapat meningkatkan pendapatan masyarakat kawasan, terbagi menjadi sub program peningkatan posisi tawar petani dan program pengembangan keterkaitan dan industri pengolahan (agroindustri). Program lainnya yaitu program pengembangan produk olahan pertanian, program pengembangan struktur tata ruang dan pusat pelayanan agropolis, program pengembangan infrastruktur dasar dan infrastruktur pendukung pertanian dan program sistem kelembagaan dan pembiayaan pengelola kawasan agropolitan.

\section{Kepengurusan POKJA dan POSKO}

Pengembangan kawasan agropolitan Kabupaten Bogor dilakukan melalui beberapa program yang mengacu pada visi dan misi program pengembangan agropolitan dengan menyesuaikan karakteristik wilayah setempat. Program yang dijalankan melibatkan beberapa stakeholders yang disesuaikan dengan kebutuhan program. Nurzain (2010) menjelaskan secara garis besar pelaksanaan program agropolitan diperlukan strategi pelaksanaan kegiatan dengan mekanisme koordinasi antar stakeholders dengan kegiatan:

1. Pembentukan Kelompok Kerja (POKJA) Agropolitan Kabupaten Bogor. Kegiatan pengembangan wilayah agropolitan tentunya melibatkan banyak pihak. Salah satu syarat lancarnya kegiatan agropolitan adalah adanya mekanisme koordinasi yang baik antara pihak yang berkepentingan dan untuk mewujudkan koordinasi baik di tingkat pusat maupun kabupaten sampai ke tingkat desa maka dibentuklah kelompok kerja (POKJA). Pembentukan POKJA di inisiasi oleh Badan Perencanaan 
Pembangunan Daerah (BAPPEDA) Kabupaten Bogor yang merupakan leading project atas kawasan agropolitan dalam pembangunan tahap awal agropolitan tahun 20052010 yang kemudian diikuti dukungan oleh satuan dinas yang lain. Selain itu, pengembangan kawasan juga diperlukan pihak lain seperti lembaga keuangan, lembaga penelitian, perwakilan masyarakat dan lembaga swasta. Sehingga pihak tersebut juga termasuk dalam Kelompok Kerja (POKJA) Kabupaten Bogor.

2. Pembentukan Pos Simpul Koordinasi (POSKO) Agropolitan Kabupaten Bogor. Fungsi pusat koordinasi juga diperlukan di tingkat desa di kawasan agropolitan agar informasi yang berasal dari dinas atau pemerintah kabupaten dapat langsung dikoordinasikan dengan masyarakat. Terkait hal tersebut maka dibentuklah POSKO (Pos Simpul Koordinasi) pada tahun 2005 yang terdiri dari perwakilan masyarakat di kawasan agropolitan. Anggota POSKO merupakan anggota kelompok tani yang menjadi PPS (Penyuluh Pertanian Swadaya). Penyuluh pertanian swadaya ini memang disiapkan untuk membantu tugas penyuluh pertanian dalam mengatasi permasalahan pertanian sekaligus sebagai penyalur informasi dari dinas tentang program maupun inovasi dan teknologi pertanian terbaru. Anggota POSKO ini berperan sebagai linkage antara dinas dengan masyarakat. Terdapat tiga POSKO di Kabupaten Bogor yang masing-masing anggotanya terdiri dari 30 orang penyuluh swadaya per POSKO. POSKO satu berada di wilayah Desa Cibeber, Pabangbon dan Karacak dengan ketuanya pak Bakri sedangkan POSKO dua berada di wilayah Barengkok, Cibatok dan Leuwiliang dengan ketuanya pak Zulfakar sedangkan POSKO tiga berada di wilayah Jasinga. Anggota POSKO merupakan PPS masingmasing POSKO.

Aktivitas POSKO agropolitan didominasi oleh rapat bulanan masing-masing POSKO yang dilaksanakan pada kamis minggu pertama tiap bulannya. Tentunya dalam setiap pertemuan membahas tentang permasalahan pertanian maupun evaluasi dampak agropolitan di tiaptiap wilayah untuk dicari solusinya bersama penyuluh, dinas dan pemerintah daerah. Selain itu, kesempatan ini merupakan sarana alat koordinasi kepada anggota POSKO yang diharapkan mampu diteruskan kepada masyarakat di wilayah POSKO tersebut serta ajang untuk memberikan masukan kepada pemerintah/dinas tentang program yang diperlukan masyarakat.

\section{Program Pengembangan Sumberdaya Manusia}

Tujuan program ini adalah meningkatkan pengetahuan petani tentang kelembagaan maupun aspek cara bertani/ budidaya tanaman yang tepat sesuai dengan teknologi terbaru. Sumberdaya manusia masyarakat tani erat kaitannya dengan kelembagaan lokal yang merupakan sarana menimba ilmu anggota kelompok tani. Program pengembangan sumberdaya manusia yang dilaksanakan di Desa Karacak berawal dari pelatihan fasilitator untuk mendampingi kelompok tani selama pelaksanaan program agropolitan.

Menurut laporan evaluasi BP3K Kecamatan Leuwiliang tahun 2011, program pengembangan sumberdaya manusia diinisiasi sejak tahun 2006 setelah pembentukan Penyuluh Pertanian Swadaya (PPS) sebagai fasilitator petani di kawasan agropolitan tahun 2004. PPS tersebut juga senantiasa dipantau dengan adanya pertemuan 3 kali sebulan di BP3K. Saat ini PPS tersebut diberi insentif sekitar Rp. 400.000 per bulan. Selain pelatihan PPS, terdapat pelatihan bagi anggota kelompok tani. Pelatihan tersebut menekankan pada budidaya komoditi unggulan agropolitan seperti manggis dan padi. Pelatihan ini merupakan bagian dari program peningkatan produktivitas pertanian komoditi potensial.

\section{Program Pengembangan Budidaya}

Program ini bertujuan untuk meningkatkan potensi komoditas unggulan yang ada di Desa Karacak, baik dalam kualitas komoditi maupun cara pengolahan komoditi. Bukan hanya komoditi manggis saja tapi juga komoditi lain seperti padi, jagung, durian dan pala. Pengembangan budidaya yang dilaksanakan berupa program Pengembangan pembibitan untuk komoditas manggis dan peternakan domba. Pihak yang banyak berperan dalam program ini adalah Dinas Pertanian. Program ini dimulai tahun 2005 berupa bantuan bibit manggis kepada tiga kelompok tani yang ada di Desa Karacak. Masing-masing kelompok tani mendapat bantuan sekitar 500 bibit manggis untuk ditanam. Pembagian bibit tersebut dilakukan melalui proses diskusi antar anggota, masing-masing anggota rata-rata mendapatkan 30 bibit manggis. Pengambilan bibit tersebut dikenakan biaya 2500/bibit untuk pengganti ongkos transportasi.

Selain bantuan bibit manggis bantuan lainnya yaitu bantuan induk ikan mas dan bantuan ternak kambing dari Dinas Peternakan. Bantuan ini bertujuan untuk menerapkan sistem integrated farming dimana hasilnya digunakan sebagai pupuk tanaman. Ternak kambing ini diberikan dengan sistem bergilir, setiap kelompok diberikan bantuan domba sebanyak 73 ekor kambing. Bantuan kambing tersebut diberikan sepasang per orang dengan syarat mau menyediakan kandang, pakan dan rumput. Hasil dari kambing yang berupa anak kambing itu kemudian dibagi menjadi dua bagian dan diserahan kembali untuk diberikan kepada anggota yang lain.

\section{Program Pengembangan Permodalan}

Tujuan pengembangan permodalan adalah membantu petani meningkatkan usahanya sehingga posisi tawar petani mampu bersaing dengan pihak lain seperti tengkulak. Program ini berupaya meningkatan kapasitas kelompok tani dan koperasi dalam permodalan. Program pengembangan permodalan yang pernah masuk ke Desa Karacak tidak lepas dari peran pemerintah daerah melalui Dinas Pertanian, Dinas Koperasi, Koperasi KBU Al-Ikhsan, PT Agung Mustika Selaras dan Rabo Bank. Program pengembangan permodalan yang di fasilitasi oleh Dinas Pertanian yaitu PUAP.

Program PUAP ini disalurkan melalui kelompok tani sebesar 50 juta per kelompok tani yang dikelola oleh bendahara Gapoktan. Dana PUAP ini hanya boleh dipinjam untuk urusan permodalan usaha. Masing-masing individu juga hanya dibatasi maksimal dua juta rupiah. Hal ini ditujukan untuk mengurangi kecemburuan sosial. Setiap kali peminjaman satu juta harus dikembalikan selama sepuluh bulan dengan total cicilan satu juta seratus ribu rupiah. Peran koperasi KBU AL-Ikhsan sebagai lembaga keuangan selain sebagai tempat pengumpulan komoditi hasil panen yang berupa manggis dan durian juga berupaya untuk menstabilkan harga jual manggis dengan cara mengurangi keuntungan dari pihak ketiga/tengkulak 
karena pengumpulannya di koperasi. Selain itu koperasi juga memperoleh dana dari pemerintah kabupaten untuk dana pinjaman kepada petani manggis.

Koperasi Al-Ikhsan meminjamkan dengan mekanisme pengembalian satu angsuran. Sedangkan pihak dinas hanya menjembatani dengan bantuan dari perbankan. Bantuan permodalan juga di tawarkan oleh PT Agung Mustika Selaras yang bergerak dibidang ekspor buah ke Thailand. Pihak swasta tersebut memberikan bantuan pembiayaan pertanian melalui pinjaman lunak yang kemudian dibayar dengan hasil panen, biasanya buah manggis. Selain itu kerjasama dibidang permodalan juga didukung oleh Rabo Bank, namun persepsi masyarakat tentang bank yang memiliki bunga besar menyebabkan peminjaman ini jarang dilakukan.

\section{Program Peningkatan Fasilitas Infrastruktur}

Program ini bertujuan untuk mempermudah mobilisasi hasil pertanian keluar wilayah dan memudahkan investor masuk ke wilayah tersebut. Secara garis besar program peningkatan fasilitas infrastruktur ini bertujuan untuk mempermudah akses menuju kawasan agropolitan. Program pertama yang dilaksanakan yaitu peningkatan jalan poros Desa Karacak. Jalan tersebut sebenarnya telah dibangun sejak tahun 1971 melalui inisiatif swadaya masyarakat. Namun sebelum adanya program agropolitan jalan tersebut telah rusak sehingga untuk memperlancar transportasi, ditahun 2006 atas nama program agropolitan dilaksanakan peningkatan jalan poros desa sejauh $3.000 \mathrm{~m}$. Selain itu juga diadakan peningkatan jalan ruas Leuwiliang-Karacak sepanjang $6 \mathrm{~km}$ dan ruas Karacak-Puraseda sejauh 4,6 $\mathrm{km}$. Pembangunan ini dilaksanakan langsung oleh Dinas Bina Marga dengan pertimbangan bahwa jalur tersebut merupakan jalur utama distribusi hasil pertanian.

Program yang berkaitan dengan irigasi pengairan dan penyediaan air baku dilaksanakan di tahun 2006 yaitu penyediaan air baku sejumlah satu unit air bersih, program ini dibutuhkan mengingat ada beberapa daerah yang masih kesulitan air. Penyelenggaraan program ini dilaksanakan oleh BAPPEDA dengan sumber dana dari APBN Kabupaten Bogor.

Program pembangunan sarana pendukung program agropolis diwujudkan dengan pembangunan tempat penyimpanan sementara/gudang manggis. Alasannya jumlah panen manggis yang melimpah dan kekhawatiran akan busuknya komoditi dapat diatasi dengan pembuatan gudang penampungan maka diperlukan pembuatan gudang/stasiun pengumpul buah-buahan di Karacak. Namun program ini tidak melibatkan masyarakat sehingga sampai saat ini penggunannya pun jarang. Peran pembuatan gudang ini didominasi oleh ketua POSKO dan aparat desa setempat. Penempatan lokasi gudang manggis ini berada di ujung Desa Karacak, dekat dengan kantor desa dan jauh dari pusat kawasan penghasil manggis di dusun Cengal sehingga fungsinya kini menjadi berkurang.

\section{Peran Stakeholders dalam Program Agropolitan}

Peran stakeholders dapat diukur dengan menggunakan tingkat pengaruh dan tingkat kepentingan stakeholders ketika menjalankan program suatu program (IFC 2007). Tingkat pengaruh dan tingkat kepentingan dilihat dari sudut pandang masyarakat terhadap pihak-pihak yang memiliki pengaruh dan kepentingan terhadap program agropolitan. Stakeholders tersebut merupakan anggota POKJA, POSKO, dan pihak lain yang berinteraksi juga dengan masyarakat ketika menjalankan program agropolitan.

Stakeholders yang diidentifikasi terlibat dalam program agropolitan tentunya harus memiliki atribut kepentingan dan pengaruh yang menentukan perannya dalam menjalankan program (IFC 2007). Menurut Reed et al. (2009) analisis stakeholders dimulai dari identifikasi stakeholders yang bertujuan untuk menemukan pihak yang mempengaruhi penyelenggaraan program agropolitan baik yang secara langsung berinteraksi dengan pihak masyarakat maupun tidak berinteraksi secara langsung. Hasil identifikasi stakeholders program agropolitan di Desa Karacak, merujuk pengklasifikasian stakeholders oleh Sriani (2012) diklasifikasikan ke dalam enam kelompok yakni pemerintah kabupaten, pemerintah desa, opinion leader, LSM, perguruan tinggi dan swasta. Stakeholders yang dicantumkan merupakan stakeholders yang telah terlibat, sedang terlibat maupun berpotensi untuk terlibat. Hasil identifikasi stakeholders disajikan pada Tabel 1.

Tingkat pengaruh stakeholders dilihat dari pengaruh 14 stakeholders agropolitan pada setiap tahapan baik dari perencanaan, pelaksanaan dan evaluasi program. Kekuatan pengaruh (power) mengacu kepada seberapa besar kemampuan materi atau dana, personality serta jaringan masing-masing stakeholders dalam mempengaruhi arah dan dinamika perkembangan program (IFC 2007). Menurut Mayer (2001), pengaruh merupakan kapasitas atau kemampuan untuk menyelesaikan suatu tujuan. Kekuatan pengaruh tertinggi terjadi apabila seseorang dengan unsurunsur kekuasaan yang dimilikinya menjangkau dari tingkat desa hingga ke tingkat kabupaten (Budimanta dkk 2008). Melihat pengaruh stakeholders dalam program agropolitan diukur dari seberapa besar kekuatan dananya, jaringan dan pengaruh personality masing-masing stakeholders dalam tiap tahapan kemudian dijumlahkan skor masing-masing stakeholders dalam semua tahapan.

\section{Tabel 1 Matriks Stakeholders Program Agropolitan}

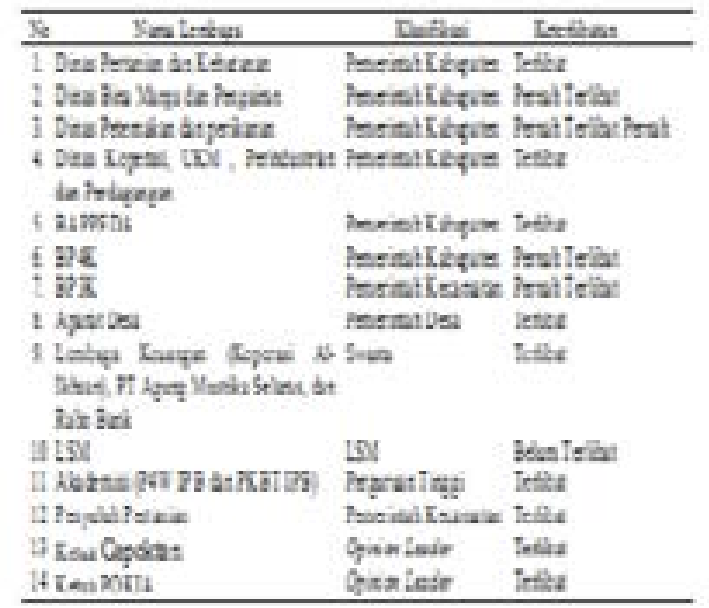

Sebenarnya masih banyak stakeholders yang tergabung selama pelaksanaan program agropolitan namun karena keterbatasan penulis maka dibatasi menjadi 14 stakeholders. 


\section{Tingkat Pengaruh Stakeholders dalam Program Agropolitan}

\section{Pengaruh Stakeholders dalam Perencanaan}

Pada tahap perencanaan, pihak yang banyak terlibat adalah BAPPEDA Kabupaten Bogor, Pihak Akademisi yaitu P4W IPB, Dinas Pertanian, aparat desa, Ketua POSKO agropolitan. Pihak dinas yang tergabung dengan POKJA agropolitan mengikuti proses perencanaan namun hanya pada saat perencanaan di tingkat kabupaten. Sedangkan di tingkat desa beberapa dinas tidak langsung berinteraksi dengan masyarakat sehingga pengaruh mereka rendah (2).

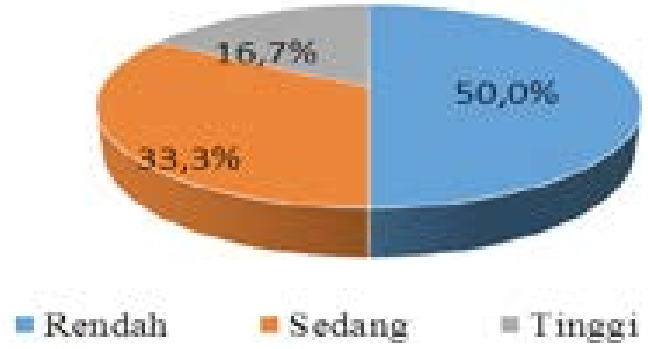

Gambar 2. Persentase Responden Berdasarkan Tingkat Pengaruh Stakeholders dalam Perencanaan Program Agropolitan

Gambar 2 menunjukan bahwa 50\% responden menyatakan bahwa pengaruh stakeholders rendah. Hanya beberapa stakeholders yang memiliki personality yang tinggi diantaranya ketua POSKO, Dinas Pertanian, dan aparat desa. Ketiga pihak itu mampu mendengarkan aspirasi masyarakat, mampu bergaul dengan masyarakat pada proses perencanaan. Sedangkan $33.3 \%$ responden menyatakan bahwa pengaruh stakeholders terbilang sedang dan $16.7 \%$ responden menyatakan bahwa pengaruh stakeholders dalam tahap perencanaan termasuk tinggi. Responden yang menyatakan bahwa pengaruh stakeholders dalam perencanaan rendah.

\section{Pengaruh Stakeholders dalam Pelaksanaan}

Pengaruh stakeholders pada tahap pelaksanaan dilihat dari pengaruhnya dalam program pengembangan sumberdaya manusia, program pengembangan budidaya, pengembangan permodalan dan program peningkatan fasilitas dan infrastruktur. Masing-masing stakeholders tentunya memiliki pengaruh sesuai dengan karakteristik yang berbeda pada masing-masing program (Gambar 3).

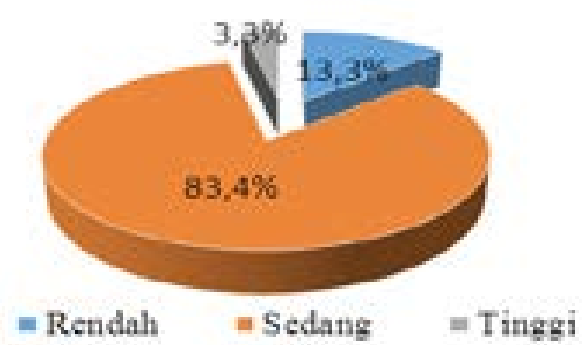

Gambar 3. Persentase Responden Berdasarkan Tingkat Pengaruh Stakeholders dalam Pelaksanaan Program Agropolitan
Pengaruh stakeholders dalam program agropolitan termasuk sedang. Penyataan tersebut didukung dengan data menunjukan bahwa $13.3 \%$ responden menyatakan pengaruh stakeholders rendah sedangkan $83.3 \%$ responden menyatakan pengaruh stakeholders sedang dalam keseluruhan program agropolitan dan $3.3 \%$ responden menyatakan bahwa pengaruh stakeholders dalam tahap pelaksanaan tinggi. Pengaruh stakeholders dalam setiap program tentunya berbeda. Pada program pengembangan sumber daya manusia dan pengembangan budidaya, Dinas Pertanian memegang pengaruh yang sangat besar mulai dari dukungan dana, jaringan dan memiliki personality yang baik, mampu dekat dengan masyarakat sebagai dinas yang bertanggung jawab dalam pengembangan sumberdaya manusia dan budidaya pertanian.

Pengaruh stakeholders pada program agropolitan juga ditentukan oleh tanggung jawabnya pada tupoksi, misalnya Dinas Bina Marga ternyata hanya berpengaruh pada tahap pelaksanaan khususnya program peningkatan infrastruktur, karena tugas pembuatan jembatan dan peningkatan jalan diberikan kepada pihak ketiga yaitu kontraktor, sehingga interaksi dengan masyarakat sangat kurang. Apalagi dalam program pengembangan permodalan, peran koperasi Al-ikhsan masih sangat dominan pada awal tahun 2006 sampai tahun 2008 dalam memberikan pinjaman dan penampungan hasil panen. Namun, akibat mekanisme pembayaran pinjaman yang terhambat sehingga koperasi kehabisan modal, ditambah lagi dengan iuran anggota yang tersendat. Upaya menampung hasil panen dan menjual kembali dengan harga yang stabil telah dilakukan oleh koperasi Al-ikhsan, namun terhambat karena kondisi sekarang, kepemilikan pohon manggis banyak dialihkan kepada investor luar desa menyebabkan masyarakat tidak mempunyai hak untuk memutuskan penjualan manggis.

\section{Pengaruh Stakeholders dalam Evaluasi}

Evaluasi secara formal oleh pihak dinas anggota POKJA agropolitan sebenarnya sudah dilaksanakan tahun 2010 2011 namun hanya mengikutsertakan dinas dan ketua POSKO saja. Sementara masyarakat tidak diikutsertakan secara langsung. Hal ini menyebabkan pengaruh stakeholders rendah pada saat evaluasi program agropolitan seperti yang ditunjukkan secara rinci pada Gambar 4.

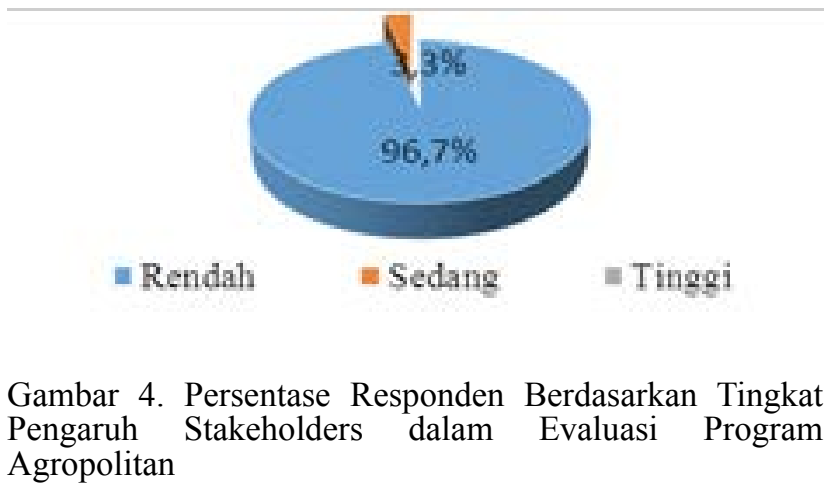

Gambar 4 menunjukan bahwa 96.7\% responden menyatakan pengaruh stakeholders rendah sedangkan $3.3 \%$ responden menyatakan pengaruh stakeholders sedang. Evaluasi secara non-formal sering dilaksanakan dalam perkumpulan kelompok tani yang diinisiasi oleh ketua POSKO agropolitan sehingga pengaruh terbesar dalam evaluasi adalah ketua POSKO agropolitan namun pihak 
lain yang tidak mengundang masyarakat untuk evaluasi langsung seperti dinas kabupaten dianggap memiliki pengaruh yang rendah pada evaluasi program.

\section{Kepentingan stakeholders dalam Perencanaan Program Agropolitan}

Kepentingan stakeholders dalam perencanaan program dilihat dari kepentingan stakeholders dalam membuat masterplan maupun kinerjanya dalam pelatihan fasilitator agropolitan yang diwujudkan dengan pelatihan PPS (Penyuluh Pertanian Swadaya), lokakarya/sosialisasi wilayah agropolitan yang dilaksanakan baik ditingkat kabupaten maupun ditingkat desa. Hasil dari lokakarya tersebut antara lain: pembagian zona wilayah agropolitan, penyusunan rencana program agropolitan dan pemetaan wilayah dalam rangka perencanaan program agropolitan. Tingkat kepentingan stakeholders pada perencanaan program, terlihat dari seberapa besar kinerja stakeholders untuk memenuhi kepentingan masyarakat ataupun organisasi dapat dilihat pada Gambar 5.

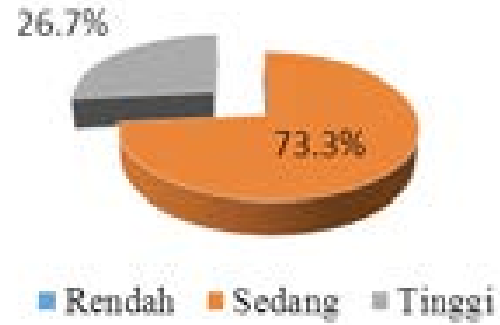

Gambar 5. Persentase Responden Berdasarkan Tingkat Kepentingan Stakeholders dalam Perencanaan Program Agropolitan

Gambar 5 menunjukan bahwa $73.3 \%$ responden menyatakan stakeholders memiliki kepentingan yang sedang dalam perencanaan program agropolitan sedangkan $26.7 \%$ responden menyatakan bahwa stakeholders memiliki kepentingan yang tinggi dalam tahap perencanaan program agropolitan. Secara garis besar pada saat perencanaan tingkat kepentingan stakeholders adalah rendah.

\section{Kepentingan stakeholders dalam Pelaksanaan Program Agropolitan}

Kepentingan stakeholders dalam penyelenggaraan program agropolitan dilihat dari kepentingannya dalam penyelenggaraan program pengembangan SDM, pengembangan budidaya, pengembangan permodalan dan program peningkatan fasilitas dan infrastruktur. Kepentingan erat kaitannya dengan keberadaan stakeholders tersebut dalam program. Renald Kasali dalam Wibisono (2007) menjelaskan bahwa stakeholders primer dalam sebuah program merupakan stakeholders paling penting. Pada pelaksanaan program agropolitan stakeholders primer yaitu pihak Dinas Pertanian, aparat desa, ketua POSKO agropolitan Desa Karacak. Tingkat kepentingan stakeholders pada pelaksanaan program dapat dilihat pada Gambar 6.

Gambar 6 menunjukan bahwa $86.7 \%$ responden menyatakan stakeholders memiliki kepentingan yang sedang dalam pelaksanaan program agropolitan sedangkan $13.3 \%$ responden menyatakan bahwa stakeholders memiliki kepentingan yang tinggi dalam tahap pelaksanaan program agropolitan. Dapat disimpulkan bahwa kepentingan stakeholders berada pada tingkat sedang. Kepentingan berada pada tingkat sedang diakibatkan oleh ada stakeholder yang memiliki tingkat kepentingan yang tinggi misalnya Ketua Gapoktan dan terdapat stakeholder yang kepentingannya sangat rendah misalnya LSM sehingga ketika ditotalkan hasilnya sedang. Bapak AMR yeng merupakan ketua kelompok tani yang selama ini berinteraksi dengan ketua POSKO menyatakan bahwa kinerjanya sebagai ketua POSKO didasari oleh motif mensejahterakan anggotanya, keputusan yang diambil dipertimbangkan menurut kebutuhan anggota kelompok tani dan dalam pembagian bantuannya selalu adil pada setiap kelompok tani.
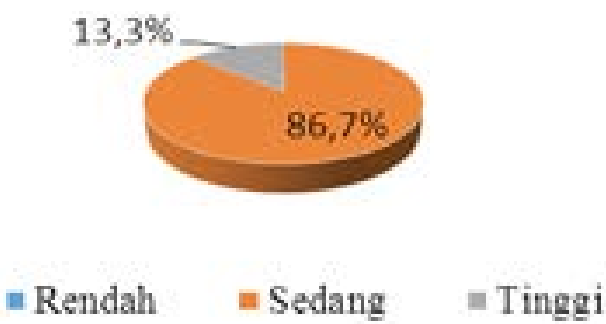

Gambar 6 Persentase Responden Berdasarkan Tingkat Kepentingan Stakeholders dalam Pelaksanaan Program Agropolitan

\section{Kepentingan stakeholders dalam Evaluasi Program Agropolitan}

Kepentingan stakeholders dalam evaluasi program dilihat dari kepentingan stakeholders dalam menilai keberhasilan program serta pelaporan hasil program agropolitan pada masyarakat. Dalam sebuah program tentunya pengukuran evaluasi harus berdasarkan kepada tujuan program. Tujuan program agropolitan adalah mensejahterakan masyarakat, namun masih ada stakeholders memiliki tujuan yang berbeda dengan tujuan program sehingga perlu dilihat sejauh mana pelaksanaan program yang dibawanya membantu masyarakat.

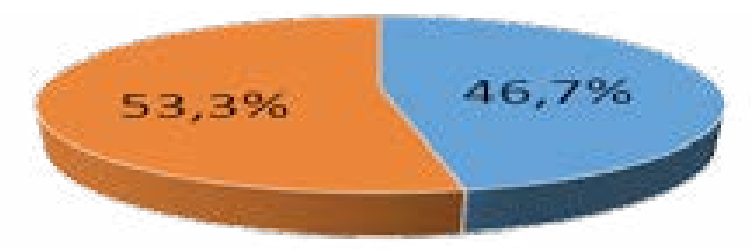

\section{Rendah Sedang Tinggi}

Gambar 7 Persentase Responden Berdasarkan Tingkat Kepentingan Stakeholders dalam Evaluasi Program Agropolitan

Gambar 7 menunjukan bahwa 53.3\% responden menyatakan stakeholders memiliki kepentingan yang sedang dalam evaluasi program agropolitan sedangkan $46.7 \%$ responden menyatakan bahwa stakeholders memiliki kepentingan rendah dalam tahap perencanaan program agropolitan. Hal ini dipengaruhi oleh tahap evaluasi program bersama dinas, LSM, dan lembaga keuangan yang tidak dilaksanakan di Desa Karacak. Pelaksanaan evaluasi ini dilakukan di 
kalangan anggota POKJA agropolitan, tidak melibatkan masyarakat hanya mengundang ketua POSKO serta aparat desa, hal tersebut yang menyebabkan kepentingan stakeholders rendah. Namun, evaluasi non formal juga dilaksanakan oleh stakeholders yang memiliki kepentingan yang tinggi dalam evaluasi yaitu ketua POSKO. Ketua POSKO dalam rapat bulanan selalu mengadakan evaluasi dan mengarahkan program agropolitan kedepannya bersama dengan BP3K dan pemerintah Kecamatan.

\section{Klasifikasi Stakeholders}

Hasil penilaian atribut stakeholders meliputi kepentingan dan pengaruh stakeholders pada program agropolitan berdasarkan hasil kuesioner dan wawancara. Klasifikasi stakeholder dalam program agropolitan dijelaskan pada Gambar 8 .

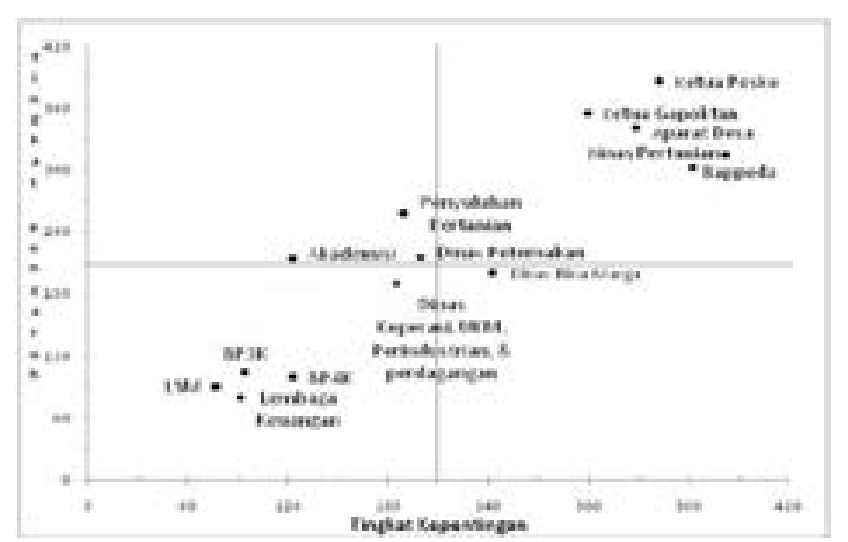

Gambar 8. Klasifikasi Stakeholders

Berdasarkan matriks tersebut, wilayah A, B, dan C,implikasi dari keberadaan stakeholders pada masing-masing kuadran adalah klasifikasi/pengolongan stakeholders menurut IFC (2007) sebagai berikut :

a) Wilayah $\mathrm{A}$ merupakan stakeholders dengan tingkat pengaruh tinggi dalam implementasi program agropolitan mulai dari perencanaan, pelaksanaan sampai evaluasi tetapi memiliki kepentingan yang rendah digolongkan menjadi keep statisfied pada mekanisme program agropolitan. Stakeholders yang termasuk keep statisfied adalah Dinas Peternakan, penyuluh pertanian dan akademisi.

b) Wilayah $\mathrm{B}$ merupakan stakeholders dengan tingkat pengaruh dan kepentingan yang tinggi dalam program agropolitan digolongkan menjadi manage closely. Stakeholders yang termasuk manage closely adalah Ketua Gapoktan, Ketua POSKO, aparat desa, Dinas Pertanian dan BAPPEDA Kabupaten Bogor.

c) Wilayah $\mathrm{C}$ merupakan stakeholders yang memiliki pengaruh rendah tetapi kepentingannya tinggi dalam program agropolitan digolongkan menjadi keep informed. Stakeholders yang termasuk dalam keep informed adalah Dinas Bina Marga.

d) Wilayah D merupakan stakeholders pada kuadran ini memiliki pengaruh dan kepentingan yang rendah dalam program agropolitan digolongkan menjadi monitor. Stakeholders yang termasuk dalam monitor adalah, Dinas Koperasi, UKM, Perindustrian, Perdagangan dan UKM, BP3K, BP4K, LSM dan Lembaga Keuangan ( Koperasi
KBU Al-Ikhsan, PT Agung Mustika selaras, dan Rabo Bank).

Matriks tersebut menjelaskan posisi stakeholders dalam program agropolitan. Dinas Bina Marga sebagai Keep Informed harus memiliki inisiatif khusus mengajak masyarakat terlibat dalam programnya bila menginginkan program yang dilaksanakannya lancar dan keberlanjutan. Ketika masyarakatmengikuti suatu program dan berinteraksi dengan stakeholder pelaksana program maka stakeholder tersebut akan dikenali masyarakat sehingga ketertarikan masyarakat dengan programnya pun diharapkan akan meningkat. Bentuk partisipasi yang diharapkan juga bukan hanya partisipasi dalam memberikan pendapat namun juga bersedia menyumbang tenaga untuk pembangunan infrastruktur program agropolitan.

Di sisi lain Ketua Gapoktan, Ketua POSKO, aparat desa, Dinas Pertanian dan BAPPEDA Kabupaten Bogor. sebagai pihak yang digolongkan menjadi manage losely yang menentukan kesuksesan berjalannya program agropolitan serta keberlanjutan program agropolitan. Pihak tersebut mampu membangun jaringan dengan stakeholders lainnya. Agar program berjalan dengan baik, stakeholders lainnya harus menjalin kerjasama dan hubungan baik dengan pihak yang digolongkan dalam manage closely tersebut. Stakeholders yang berperan sebagai keep statisfied dalam program ini adalah Dinas Peternakan, penyuluh pertanian dan akademisi yang membutuhkan manajemen dan dukungan yang lebih besar lagi dari pihak manage closely dalam melanjutkan program agropolitan kedepannya. Stakeholders ini mampu mempegaruhi jalannya program agropolitan dan menghambat program bila tidak dilibatkan, sehingga harus diperhatikan.

Sedangkan stakeholders yang menjadi crowd yaitu Dinas Koperasi, UKM, Perindustrian dan Perdagangan, BP3K, BP4K, LSM dan lembaga keuangan bukan merupakan subyek atau pihak yang berpengaruh besar dalam keberlanjutan program agropolitan, sehingga hanya dibutuhkan monitoring dan evaluasi dalam prioritas yang rendah. Kenyataannya pada saat pelaksanaan pihak yang tergolong dalam crowd tersebut hadir, namun intensitasnya tidak sebanyak pihak yang berada pada wilayah manage closely, keep informed dan keep statisfied.

\section{Tingkat Partisipasi Masyarakat dalam Program Agropolitan}

Tingkat partisipasi adalah derajat keikutsertaan anggota dalam semua tahapan kegiatan sesuai dengan gradasi derajat wewenang dan tanggung jawab yang dapat dilihat dalam proses pengambilan keputusan. Adapun kedelapan tingkatan partisipasi tersebut yaitu tahap manipulasi, terapi, pemberitahuan, konsultasi, penenangan, kemitraan, pendelegasian kekuasaan, dan kontrol masyarakat kemudian diringkas menjadi citizen power, tokenisme dan non-partisipasi (Arnstein 1969). Dalam tahapannya keseluruhan program tentunya memerlukan partisipasi masyarakat. Secara keseluruhan partisipasi masyarakat masih berada di tingkat tokenisme seperti yang diperlihatkan pada Tabel 2 berikut.

Tabel 2 menjelaskan jumlah dan persentase partisipasi masyarakat dalam keseluruhan program, yang juga digambarkan pada setiap tahapan program mulai dari perencanaan, pelaksanaan, dan evaluasi. Secara 
keseluruhan tingkatan partisipasi masyarakat berada di tingkat citizen power sebanyak $6.7 \%$ sedangkan $40 \%$ responden berada di tingkat non-partisipasi, sementara sebagian responden berada di tingkat partisipasi tokenisme yaitu sebanyak 53.3\%. Gambar tersebut menunjukan bahwa tingkat partisipasi masyarakat pada program agropolitan tahun 2004-2010 di Desa Karacak masih kurang, secara keseluruhan partisipasi masyarakat sebagian masyarakat masih berada pada derajat partisipasi tokenisme.

\section{Tabel 2. Jumlah dan Presentase Tingkat Partisipasi Masyarakat dalam Program Agropolitan}

\begin{tabular}{lcccccc}
\hline & \multicolumn{5}{c}{ Tingkatan Partisipasi Masyarakat } \\
\cline { 2 - 7 } \multicolumn{1}{c}{ Tahap } & $\begin{array}{c}\text { Non Par- } \\
\text { tisipasi }\end{array}$ & $\%$ & $\begin{array}{c}\text { Token- } \\
\text { isme }\end{array}$ & $\begin{array}{c}\text { Cit- } \\
\text { izen } \\
\text { Pow- } \\
\text { er }\end{array}$ & $\%$ \\
\hline $\begin{array}{l}\text { Keseluru- } \\
\text { han }\end{array}$ & 40.0 & 16 & 53.3 & 2 & 6.7 \\
$\begin{array}{l}\text { Pe re n c a - 19 } \\
\text { naan }\end{array}$ & 63.3 & 8 & 26.7 & 3 & 10.0 \\
$\begin{array}{l}\text { Pe lak s a - 8 } \\
\text { naan }\end{array}$ & 26.7 & 20 & 66.7 & 2 & 6.7 \\
Evaluasi & 22 & 73.3 & 6 & 20.02 & 6.7 \\
Total & 30 & 100 & 30 & 100 & 30 & 100 \\
\hline
\end{tabular}

Pada tahap perencanaan program agropolitan dapat terlihat bahwa derajat partisipasi masyarakat yang dominan berada di tingkat non partisipasi yaitu sebanyak $63.3 \%$ sedangkan sebanyak $26.7 \%$ masyarakat berada di tingkat tokenisme sisanya yaitu $10 \%$ berada di tingkat citizen power. Ini menunjukan bahwa masyarakat yang dilibatkan dalam perencanaan masih cenderung kurang. Masyarakat hanya menerima informasi perencanaan Desa Karacak menjadi wilayah agropolitan namun sebagian besar konsep baik berupa tata ruang maupun program kegiatan yang akan dilaksanakan ditentukan oleh dinas yang berwenang. Masyarakat yang berpartisipasi dalam perencanaan hanya sebatas memberikan saran, keputusan tentang pembangunan awal agropolitan masih menjadi wewenang dinas.

Derajat partisipasi masyarakat pada tahap pelaksanaan sebagian besar berada pada tingkat tokenisme dengan persentase sebesar $66.7 \%$ namun masih ada masyarakat yang berada di tingkat non-partisipasi sebesar $26.7 \%$. Hasil tersebut menunjukan bahwa masyarakat masih belum mampu menjadi salah satu pihak yang mengambil keputusan untuk menentukan program pengembangan kawasan agropolitan bersama dengan dinas, hanya $6.7 \%$ masyarakat yang memiliki wewenang bersama dengan dinas untuk menentukan langkah atau program yang diperlukan dalam pembangunan kawasan agropolitan.

Pada tahap evaluasi, partisipasi masyarakat masih sangat rendah, hal ini dapat dilihat dari persentase non-partisipasi yaitu sebesar $73.3 \%$. Masyarakat yang mampu memberikan pendapat/masukan terkait dengan keseluruhan program agropolitan digolongkan dalam derajat partisipasi tokenisme hanya sebesar $20 \%$ sedangkan yang berada pada derajat citizen power sebesar $6.7 \%$. Hal tersebut dikarenakan secara formal evaluasi bersama antara masyarakat dengan pemerintah belum pernah diadakan, sehingga masyarakat mampu berpartisipasi dalam evaluasi ketika rapat POSKO bersama dengan Ketua Gapoktan ataupun Ketua POSKO lalu pihak tersebut yang menyampaikan kepada pemerintah.

\section{Bentuk Partisipasi}

Bentuk partisipasi masyarakat dalam program agropolitan sendiri didominasi oleh bentuk partisipasi menyumbang pikiran baik dalam perencanaan, pelaksanaan dan evaluasi. Dilihat dari tingkat partisipasi masyarakat dalam perencanaan, pelaksanaan dan evaluasi bahwa tingkat partisipasi tertinggi berada pada tahap tokenisme sehingga mayoritas masyrakat hanya menyumbang pendapat, hal ini terlihat pada Gambar 15 dibawah ini.

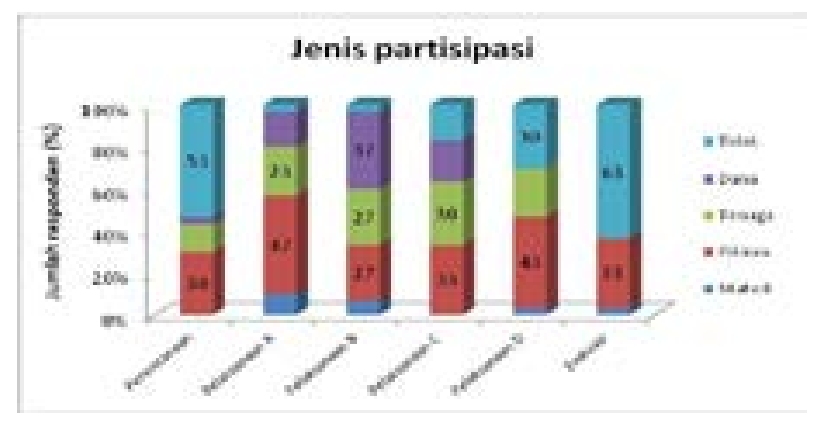

Gambar 9. Jumlah dan Persentase Bentuk Partisipasi Masyarakat

Gambar 15 menunjukan jumlah dan persentase bentuk partisipasi masyarakat dalam setiap tahapan program agropolitan. Setiap tahapan pembangunan agropolitan, mayoritas masyarakat tidak berpartisipasi pada pada tahap perancanaan dan evaluasi. Bagi masyarakat yang berpartisipasi, mayoritas masyarakat berpartisipasi dengan menyumbang pikiran berupa usulan program dan materi pelatihan serta usulan tempat kegiatan. Sedangkan urutan kedua yaitu menyumbang tenaga dengan ikut hadir dalam program. Urutan yang ketiga yaitu menyumbang dana. Dana yang disumbang sebagian besar merupakan dana iuran untuk pengambilan bantuan bibit manggis, bantuan asiltan seperti pupuk dan dana transportasi ketempat pelatihan.

Tahap perencanaan didominasi dengan sosialisasi dan pengenalan program kepada penduduk setempat atau "pemilik wilayah". Undangan sosialisasi dan lokakarya yang diadakan tidak disebarkan keseluruh masyarakat sehingga 53\% masyarakat tidak berpartisipasi dalam program. Sosialisasi tersebut fokus pada sasaran masyarakat tani yaitu kelompok tani, sehingga 30\% masyarakat berpartisipasi secara langsung dengan mengikuti sosialiasasi sekaligus memberikan pendapat.

Tahap pelaksanaan program khususnya program pengembangan SDM terbilang mampu menarik masyarakat khususnya kelompok tani untuk berpartisipasi. Partisipasi terbanyak yaitu sebesar $47 \%$ berupa partisipasi dalam memberikan pendapat yaitu usulan pelatihan bagi anggota kelompok tani berkaitan dengan manajemen kelompok tani dan usulan tempat pelaksanaan program seperti SPLHT dan pelatihan budidaya manggis maupun padi. Sisanya masyarakat berpartisipasi dalam bentuk dukungan dana berupa dana transportasi sekolah lapang, dana koordinasi rapat POSKO, serta dana transportasi musyawarah kelompok tani agropolitan. 


\section{HUBUNGAN PERAN STAKEHOLDERS DENGAN PARTISIPASI MASYARAKAT}

\author{
Hubungan Peran Stakeholders dengan Partisipasi \\ Masyarakat pada Keseluruhan Tahapan Progam \\ Agropolitan
}

Hubungan antara peran stakeholders dengan partisipasi masyarakat dilihat melalui perhitungan uji korelasi Rank Spearman dengan menggunakan alat bantu SPSS v.17.0. Nilai alpha yang digunakan sebesar 0,05 atau $5 \%$. Hasil pengujian menghasilkan angka korelasi antara variabel tingkat partisipasi masyarakat (keseluruhan tahapan) dan variabel peran stakeholders keseluruhan tahapan adalah sebesar 0.035, karena p-value (Sig.(2-tailed)) < alpha $(0.05=5$ persen $)$ maka tolak Ho dan terima H1, artinya terdapat hubungan antara variabel peran stakeholders (keseluruhan tahapan) dengan variabel tingkat partisipasi masyarakat. Korelasi antara kedua variabel tersebut berhubungan secara signifikan sehingga semakin tinggi peran stakeholders pada keseluruhan tahapan berpengaruh pada peningkatan partisipasi masyarakat.

Hal ini memperlihatkan secara dukungan dana, jaringan dan personality yang dimiliki stakeholders juga mempengaruhi partisipasi masyarakat disebabkan karena dukungan dana yang diberikan mampu mendorong masyarakat untuk ikut serta dalam program. Motif partisipasi masyarakat karena rasa aman bahwa mereka tidak akan mengeluarkan biaya saat berpartisipasi dan bebas untuk mengusulkan berbagai program. Jaringan stakeholders mempengaruhi partisipasi masyarakat karena dengan luasnya jaringan yang dimiliki oleh stakeholders, terutama stakeholders yang diklasifikasikan dalam Manage Closely menyebabkan masyarakat lebih leluasa dalam menyampaikan pendapatnya dalam program agropolitan. Personality yang menunjukan kepribadian stakeholders mampu memberikan kesempatan kepada masyarakat untuk menyalurkan pikiran dan pendapatnya sehingga mempengaruhi tingkat partisipasi masyarakat di Desa Karacak untuk menjalankan program agropolitan secara keseluruhan.

\section{Hubungan Peran Stakeholders dengan Partisipasi Masyarakat pada Tahap Perencanaan Progam Agropolitan}

Uji kedua dilakukan untuk mengetahui hubungan antara peran stakeholders pada tahap perencanaan dan variabel partisipasi masyarakat dalam tahap perencanaan. Berdasarkan hasil pengujian, didapatkan angka korelasi antara variabel peran stakeholders (tahap perencanaan) dan variabel partisipasi masyarakat dalam tahapan perencanaan berkorelasi namun tidak signifikan. Nilai koefisien korelasi Spearman yang diperoleh untuk kedua variabel tersebut sebesar 0.339 dengan nilai signifikansi sebesar 0.066 . Oleh karena nilai signifikansi tersebut lebih besar daripada nilai alfa (0.05) maka hipotesis penelitian ditolak (terima $\mathrm{H} 0$ ), dengan kata lain semakin tinggi peran stakeholders maka belum tentu partisipasi masyarakat juga tinggi. Hubungan ini dilihat dari hubungan pengaruh stakeholders dan kepentingan stakeholders dalam perencanaan program agropolitan.

Pengaruh stakeholders yang rendah pada personality dan sempitnya jaringan stakeholders pada saat sosialisasi, pembuatan masterplan, pelatihan fasilitator dan pembuatan masterplan agropolitan di awal menyebabkan keterlibatan masyarakat juga rendah. Hal ini ditunjukan dengan nilai signifikasi korelasi yaitu 0.000 , karena nilai tersebut lebih kecil dari $\alpha(0.05)$ yang menunjukan dukungan dana pada saat perencanaan program dan personality stakeholders pada saat perencanaan program mempengaruhi tingkat partisipasi masyarakat. Masyarakat menjadikan sikap stakeholders dan sikap stakeholders yang mau mendengarkan pendapat masyarakat di awal program sebagai motivasi yang mendorong keterlibatannya dalam program agropolitan.

Selain itu, luasnya jaringan/relasi yang dimiliki oleh stakeholders mampu meyakinkan masyarakat untuk mengambil kesempatan berpartisipasi dalam perencanaan program seperti halnya bapak AFR, bapak ini merupakan anggota PPS senior bersama dengan Ketua POKJA yang pertama kali mengetahui program agropolitan dari lurah setempat. Mengingat bapak AFR mengetahui tentang diri pak lurah yang memiliki banyak relasi akhirnya meyakinkan bapak AFR untuk hadir dalam perencanaan.

Sedangkan variabel dukungan dana pada perencanaan tidak memiliki hubungan dengan tingkat partisipasi masyarakat pada perencanaan program. Terbukti dengan nilai signifikasi pada uji korelasi Rank Spearman menghasilkan angka 0.117 yang berarti lebih besar dari $\alpha(0.05)$ maka hipotesis ditolak dan tidak menunjukan adanya hubungan pengaruh. Mengingat program masih awal dan baru diperkenalkan, pengetahuan tentang manfaat program juga masih rendah, maka dukungan dana yang tinggi pun tidak mempengaruhi tingkat partisipasi masyarakat. Saat tahap perencanaan agropolitan ini dinas pertanian dan BAPPEDA yang banyak berperan dalam dukungan dana untuk pembuatan masterplan bersama dengan akademisi yaitu pihak P4WIPB dengan ketua POSKO. Saat lokakarya didesa juga pihak Dinas Pertanian dan BAPPEDA bersama aparat desa yang banyak menentukan keputusan program sehingga peran mereka dominan sebagai manage closely. Dominannya peran mereka dan pengetahuan masyarakat yang masih rendah terhadap program juga menyebabkan masyarakat hanya hadir sebagi formalitas dan kalaupun memberikan pendapat tidak dipertimbangkan menyebabkan tingkat partisipasi masyarakat berada di tingkat non partisipasi dan tokenisme.

Peran stakeholders juga ditentukan oleh variabel kepentingan stakeholders. Hanya stakeholders yang dikenal oleh masyarakat sebelum adanya agropolitan yang dianggap memiliki kepentingan tinggi namun juga tidak menyebabkan partisipasi masyarakat di tingkat citizen power yang menentukan arah program dan masyarakt juga belum menjadi pihak yang dijadikan penentu kebijakan dalam penyusunan masterplan. Biasanya tokoh seperti Ketua Gapoktan dan Ketua POSKO yang berperan dalam menentukan kawasan, membantu pembuatan masterplan dan pelatihan pendamping PPS

\section{Hubungan Peran Stakeholders dengan Partisipasi Masyarakat pada Tahap Pelaksaanan Progam Agropolitan}

Uji ketiga dilakukan untuk mengetahui hubungan antara peran stakeholders pada tahap pelaksanaan dan variabel partisipasi masyarakat dalam tahap pelaksanaan. Berdasarkan hasil pengujian, didapatkan angka korelasi antara variabel peran stakeholders (tahap pelaksanaan) dan variabel partisipasi masyarakat dalam tahapan pelaksanaan 
program agropolitan berkorelasi dan signifikan. Nilai koefisien korelasi Spearman yang diperoleh untuk kedua variabel tersebut sebesar 0.410 dengan nilai signifikansi sebesar 0.24. Oleh karena nilai signifikansi tersebut lebih kecil daripada nilai alfa $(0.05)$ maka tolak $\mathrm{H} 0$ dan terima $\mathrm{H} 1$ yang artinya semakin tinggi peran stakeholders maka tingkat partisipasi masyarakat juga semakin tinggi. Hubungan ini dapat dilihat dari hubungan pengaruh stakeholders dan kepentingan stakeholders dalam pelaksanaan program agropolitan terhadap partisipasi masyarakat. Pada tahap pelaksanaan pengaruh stakeholders mempengaruhi tingkat partisipasi masyarakat.

Hal ini mengindikasikan pada saat pelaksanaan program pengaruh stakeholders yang rendah dalam pelaksanaan menyebabkan partisipasi masyarakat berada di tingkat nonpartisipasi. Dilihat dari variabel pengaruh, yang terdiri dari dukungan dana, luas jaringan, dan personality stakeholders lebih kecil dari nilai alfa $(0.05)$ sehingga menyebabkan dukungan dana, luas jaringan dan personality yang dimiliki stakeholders berhubungan dengan partisipasi masyarakat dilihat dari nilai signifikasi korelasi antara dukungan dana dengan tingkat partisipasi masyarakat pada tahap pelaksanaan yaitu 0.047 yang lebih kecil dari nilai alfa (0.05). Hal ini menyatakan bahwa semakin besar dukungan dana yang diberikan oleh stakeholders maka tingkat partisipasi masyarakat juga semakin tinggi. Masyarakat merasa dukungan dana dapat memudahkan melaksanakan program, mereka menjadi lebih bersemangat mengikuti program dan mengalokasikan dana sesuai dengan kebutuhan, aspirasi dan keinginan mereka.

Dukungan dana ini juga membuat masyarakat memperoleh hak untuk mengatur program lebih fleksibel pilihan program agropolitan yang akan dilaksanakan sesuai dengan kemampuan mereka. Pada kasus program pengembangan SDM, dukungan dana yang besar bagi pelatihan PPS atau biasa disebut dengan "uang lelah" yang tinggi menyebabkan anggota kelompok tani yang tergabung dalam PPS menjadi merasakan kemudahan dalam mobilisasi mengujungi petani karena tidak khawatir akan kesulitan ongkos. Dukungan dana yang tinggi telah menjadikan tingkat partisipasi menjadi lebih tinggi yaitu di tingkat citizen power karena selain itu juga dengan sisa uang transportasi PPS mampu terlibat dalam merancang program pembinaan kelompok tani yang lebih kreatif dan efektif bagi peningkatan kesejahteraan petani.

Seperti halnya pada program pengembangan SDM, dukungan dari dinas untuk pembiayaan berbagai pelatihan dari pelatihan budidaya padi dan manggis, pelatihan fasilitator dan pemberian bantuan pertanian demi meningkatkan pendapatan petani dianggap menguntungkan petani sehingga menyebabkan petani banyak berpartisipasi. Berbeda dengan kasus pembuatan jembatan Ciletuh ilir yang dibangun oleh Dinas Bina Marga. Dukungan dana sepenuhnya berasal dari pemerintah daerah yang salurkan melalui pemborong. Namun ketika ditanya keterlibatannya dalam program, masyarakat merasa tidak berpartisipasi karena masyarakat tidak mengetahui keberadaan program sehingga walaupun dukungan dana Dinas Bina Marga tinggi namun masyarakat tidak berpartisipasi. Melalui kasus ini munculah faktor lain yang mempengaruhi partisipasi masyarakat yaitu pengetahuan terhadap keberadaan program.

Selain itu dari keseluruhan program pada tahap pelaksanaan agropolitan, luas jaringan juga mempengaruhi tingkat partisipasi masyarakat didukung dengan hasil uji korelasi antara luas jaringan dengan tingkat partisipasi masyarakat pada tahap pelaksanaan dengan nilai signifikasi 0.013 yang lebih kecil dari nilai alfa (0.05), menyatakan bahwa luas jaringan yang dimiliki oleh stakeholders juga mempengaruhi tingkat partisipasi masyarakat. Semakin banyak pihak yang terlibat dalam suatu program maka minat masyarakat untuk berpartisipasi juga semakin tinggi. Karena dengan luasnya jejaring yang dimiliki oleh stakeholders tersebut, program menjadi lebih bervariatif dan saling mendukung misalnya saat sekolah lapang, tingkat partisipasi masyarakat tinggi karena pada saat program berlangsung pihak dinas pertanian, UPTD Kecamatan Leuwiliang, penyuluh pertanian, dan ahli dari PKBT IPB terjun langsung menyebabkan masyarakat lebih leluasa menentukan materi pelatihan dan mengusulkan program pelatihan untuk sekolah lapang pekan depannya.

Hal ini juga didukung dengan sikap dari pihak dinas, PKBT IPB, dan penyuluh pertanian yang bersedia mendengar saran dari petani menyebabkan program berjalan sesuai dengan keinginan dan kebutuhan petani. Kondisi tersebut mendukung hasil uji korelasi antara personality stakeholders dengan tingkat partisipasi masyarakat yang menghasilkan nilai 0.004 lebih kecil dari alfa (0.05) mengindikasikan bahwa sikap stakeholders yang besedia mendengarkan saran masyarakat mempengaruhi tingkat partisipasi masyarakat.

Pada tahap pelaksanaan ini, partisipasi masyarakat didominasi oleh tingkat partisipasi tokenisme artinya masyarakat sudah mampu memberikan usulan pendapat namun belum memiliki wewenang dan kekuatan yang tinggi dalam mempengaruhi program agropolitan.

\section{Hubungan Peran Stakeholders dengan Partisipasi Masyarakat pada Tahap Evaluasi Progam Agropolitan}

B Uji keempat dilakukan untuk mengetahui hubungan antara variabel peran stakeholders (tahap evaluasi) dengan variabel partisipasi masyarakat. Berdasarkan hasil pengujian menggunakan rank spearman, didapatkan angka korelasi antara variabel peran stakeholders (tahap evaluasi) dan variabel partisipasi masyarakat dalam evaluasi program agropolitan berkorelasi dan signifikan. Nilai koefisien korelasi Spearman yang diperoleh untuk kedua variabel tersebut sebesar 0.382 dengan nilai signifikansi sebesar 0.037 Oleh karena nilai signifikansi tersebut lebih kecil daripada nilai alfa $(0.05)$ maka tolak $\mathrm{H} 0$ dan terima $\mathrm{H} 1$, artinya semakin tinggi peran stakeholders maka partisipasi masyarakat juga tinggi.

Pada tahapan evaluasi program agropolitan di tahun 2010, kunjungan dan interaksi Dinas Pertanian, Dinas Bina Marga, Dinas Peternakan dan Perikanan serta stakeholders lainnya kecuali ketua POSKO dan ketua POKJA dengan masyarakat mulai berkurang. Intensitas kehadiran dalam rapat POSKO juga mulai berkurang, sehingga masyarakat sendiri mulai merasa kehilangan motivasi untuk terlibat dalam melanjutkan program. Hal ini juga menunjukan bahwa ketika peran stakeholders rendah, maka partisipasi masyarakat juga rendah.

Hasil pengolahan data mengenai hubungan antara peran stakeholders dengan tingkat partisipasi masyarakat menunjukkan bahwasanya peran stakeholders memiliki 
hubungan korelasi yang signifikan terhadap partisipasi masyarakat. Itu artinya bahwa semakin tinggi peran stakeholders maka semakin tinggi pula keterlibatan masyarakat baik menyumbang pendapat, menyumbang dana, menyumbang materi ataupun tenaga dalam penyelenggaraan program agropolitan.

\section{KESIMPULAN DAN SARAN}

\section{Kesimpulan}

Penyelenggaraan program agropolitan berawal dari keputusan pemerintah pusat yang ditujukan bagi pembangunan pertanian pedesaan dalam kasus ini adalah pedesaan di Kabupaten Bogor. Sasarannya adalah kelompok tani di Kabupaten Bogor. Sebagai program pembangunan wilayah kerjasama antar stakeholders menjadi poin penting dari keberlanjutan program. Interaksi tiap-tiap stakeholders dengan masyarakat kemudian memunculkan peran dalam program agropolitan yang ditentukan oleh faktor pengaruh dan kepentingan stakeholders. Pemerintah Kabupaten Bogor yang tergolong dalam manage closely melaksanakan tahapan agropolitan dengan dukungan masyarakat. Tentunya dalam pelaksanaan dinas tersebut menjadi pendukung utama dengan memberikan pengaruh mulai dari dukungan dana sampai peningkatan fasilitas agropolitan dari tahap awal sampai evaluasi.

Terkait klasifikasi stakeholder, terdapat perbedaan klasifikasi tiap-tiap stakeholders. Berdasarkan peran stakeholders yang termasuk keep statisfied adalah Dinas Peternakan, penyuluh pertanian dan akademisi. Stakeholders yang termasuk manage closely adalah Ketua Gapoktan, Ketua POSKO, aparat desa, Dinas Pertanian dan BAPPEDA Kabupaten Bogor. Stakeholders yang termasuk dalam keep informed adalah Dinas Bina Marga. Stakeholders yang termasuk dalam monitor adalah Dinas Koperasi, UKM, Perindustrian, Perdagangan dan UKM, BP3K, BP4K, LSM dan Lembaga Keuangan. Supaya program agropolitan ini berkelanjutan hendaknya peran pihak yang tergolong manage closely memberikan kekuatan pengaruh yang lebih besar lagi pada program agropolitan serta berupaya untuk memperbesar kesempatan kepada masyarakat untuk terlibat dalam ikut merumuskan dan menentukan jalannya program agropolitan mulai dari program pengembangan SDM, pengembangan budidaya, pengembangan permodalan dan infrastruktur.

Partisipasi masyarakat secara keseluruhan program agropolitan berada pada tahap tokenisme yang memiliki kesempatan untuk berpendapat, namun tidak memiliki wewenang dan kekuatan untuk mengatur program agropolitan secara keseluruhan. Namun terdapat perbedaan saat perencanaan dan evaluasi dimana partisipasi masyarakat berada pada tahap non partisipasi. Sebagian besar bentuk partisipasi masyarakat adalah partisipasi dalam memberikan pendapat dalam program walaupun terdapat masyarakat yang menyumbang dana dan materi dengan jumlah lebih sedikit. Namun pada tahap perencanaan dan evaluasi terdapat perbedaan yaitu sebagian besar masyarakat tidak berpartisipasi.

Hasil penelitian menunjukkan bahwasanya peran stakeholders berhubungan dengan partisipasi masyarakat dalam penyelenggaraan program agropolitan. Hal ini disebabkan oleh pengaruh yang terdiri dari dukungan dana, personality serta jaringan stakeholders dan kepentingan stakeholders mampu mempengaruhi tingkat partisipasi masyarakat. Namun jika dilihat dari setiap tahapan program agropolitan, pada tahapan perancanaan tidak terdapat hubungan antara kedua variabel tersebut. Sehingga dapat disimpulkan bahwa dalam melihat hubungan peran stakeholders dengan partisipasi masyarakat tidak parsial dalam satu tahapan saja.

\section{Saran}

Mengacu pada hasil penelitian, maka terdapat beberapa hal yang dapat dijadikan masukan atau saran, diantaranya:

1. Sebaiknya stakeholders yang merupakan dinas pelaksana melakukan pendekatan intensif terhadap masyarakat dalam semua tahapan sehingga tercipta hubungan yang lebih harmonis, dan membangun kerjasama yang baik dalam pelaksaaan program kedepannya

2. Bimbingan dari pihak dinas tidak terhenti sampai program agropolitan selesai namun juga pasca program, karena dengan kondisi partisipasi yang belum baik menyebabkan program tersebut tidak dapat berkelanjutan jika tanpa pemantauan dari pemerintah.

3. Lembaga non formal yang ada di masyarakat seperti koperasi dan "Cendawasari" sebaiknya diarahkan sebagai pihak yang diberi tanggung jawab untuk melanjutkan program agropolitan.

4. Pentingnya peningkatan kinerja PPS sebagai motor penggerak program sekaligus motivator bagi kelompok tani dalam melanjutkan program agropolitan. Selain itu juga perlu peningkatan keaktifan PPS dalam menangani permasalahan pertanian yang dialami kelompok tani.

5. Harapannya masyarakat ikut merencanakan, menggerakkan, melaksanakan dan juga mengontrol pelaksanaan program agropolitan dan penataan ruang kawasannya sehingga tercipta kesadaran hukum masyarakat akan pentingnya tata ruang kawasan agropolitan.

6. Setiap tahapan program agropolitan harus mendorong masyarakat dan stakeholders agar selalu berkoordinasi dan berhubungan dengan instansi pemerintah terkait. Hal inilah yang mampu menjadikan masyarakat dan dunia usaha menjadi pelaku langsung dan objek dari program pengembangan kawasan agropolitan.

7. Peran pihak yang termasuk dalam manage closely harus dominan dan berlanjut dalam mendampingi masyarakat pada program agropolitan.

\section{DAFTAR PUSTAKA}

Ariyani I. 2007. Penguatan partisipasi masyarakat dalam program imbal swadaya di desa curug kecamatan Gunung Sindur Kabupaten Bogor. [Tesis]. Bogor [ID]: Institut Pertanian Bogor.120 hal.

Arnstein S. 1969 [Juli]. A Ladder of citizen participation. JAIP [35-4]: halaman 216-224.

[BAPPEDA] Badan Perencanaan Daerah. 2010. Evaluasi 
pelaksanaan agropolitan Propinsi Jawa Barat. [tidak diterbitkan].

[BP4K] Badan Pelaksana Penyuluhan Pertanian, Perikanan, dan Kehutanan Kabupaten Bogor. 2012. Agropolitan Kabupaten Bogor.[tidak diterbitkan].

Bryson JM. 2004. What to do when stakeholders matter: stakeholders identification and analysis techniques. Public management review. Vol 6 . 2004:21-53.

Budimanta A, Rudito B dan Prasetijo A. 2008. Corporate social responsibility: jawaban bagi pembangunan Indonesia masa kini. Jakarta [ID]: Indonesia Business Link.

Data Monografi Desa Karacak. 2011. [tidak diterbitkan].

[DEPTAN] Departemen Pertanian. 2002. Pedoman umum pengembangan kawasan agropolitan dan pedoman program rintisan pengembangan kawasan agropolitan. Departemen Pertanian RI. Jakarta.

Ditjen Penataan Ruang. 2001. Pedoman agropolitan untuk penataan ruang dan wilayah. [Internet]. 07:25 [Diunduh 2012 Februari 28]. www.penataanruang. net/taru/nspm/6.pdf.

Djakapermana RD. 2003. Pengembangan kawasan agropolitan dalam rangka pengembangan wilayah berbasis rencana tata ruang wilayah nasional (RTRWN). Direktur Jendral Penataan Ruang Departemen Permukiman dan Prasarana Wilayah Republik Indonesia. [tidak diterbitkan].

Friedman J and Douglass M.1975. Agropolitan development: towards a new strategy.[Internet]. 12:15 [Diunduh 2012 September 21]. www.nepjol. info/index.php/HR/article/download/4494/3749.

Groenendijk L. 2003. Stakeholders analysis or stakeholder engagement in government program. [Internet]. 12:35 [Diunduh 2012 September 21]. www.itc.nl/ library/papers_2003/tech_rep/groenendijk.pdf.

[IFC] International Finance Corporation. 2007. Stakeholders Engagement [Internet]. 13:12 [Diunduh 2012 Desember 21]. http://www.ifc.org/ifcext/enviro. nsf/attachmentsbytitle/p_stakeholdersengagement_ full/\$file/ifc_stakeholdersengagement.pdf.

Reed MS, Graves A, Dandy N, Posthumus H, Hubacek $\mathrm{K}$, morris J, Prell C, Quinn $\mathrm{CH}$, Stringer LC. 2009. Who's in and Why? A Typhology of Stakeholder Analysis Methods for Natural Resources Management. Jounal of Environmental Management xxx: 1-17.

Rustiadi E, Hadi S, dan Ahmad W M. 2006. Kawasan agropolitan konsep pembangunan desa-kota berimbang. Bogor :Crestpent Press.

Sukada S et al. 2007. CSR for better life: Indonesian context. Membumikan bisnis berkelanjutan memahami konsep dan praktik tanggung jawab sosial perusahaan. Jakarta [ID]: Indonesia Business Link. 190 hal.
Tarsudi. 2011. Dampak pembangungan kawasan agropolitan terhadap pengembangan wilayah dan pemberdayaan masyarakat pada lokalita saribu dolok kecamatan silimakuta kabupaten simalungun [Tesis]. Medan [ID]: Universitas Sumatera Utara. 